\title{
Regulation of satellite cell function in sarcopenia
}

\author{
Stephen E. Alway ${ }^{1,2,3 *}$, Matthew J. Myers ${ }^{1}$ and Junaith S. Mohamed ${ }^{1}$ \\ ${ }^{1}$ Laboratory of Muscle Biology and Sarcopenia, Department of Exercise Physiology, West Virginia University School of Medicine, Morgantown, WV, USA \\ ${ }^{2}$ West Virginia Clinical and Translational Science Institute, Morgantown, WV, USA \\ ${ }^{3}$ Center for Cardiovascular and Respiratory Sciences, Morgantown, WV, USA
}

Edited by:

Emanuele Marzetti, Catholic

University of the Sacred Heart, Italy

Reviewed by:

Stephanie Wohlgemuth, University of

Florida, USA

Hans Degens, Manchester

Metropolitan University, UK

\section{*Correspondence:}

Stephen E. Alway, Laboratory of

Muscle Biology and Sarcopenia,

Department of Exercise Physiology,

Robert C Byrd Health Sciences

Center, West Virginia University

School of Medicine, 1 Medical Center

Drive, P.O. Box. 9227, Morgantown,

WV 26506, USA

e-mail: salway@hsc.wvu.edu
The mechanisms contributing to sarcopenia include reduced satellite cell (myogenic stem cell) function that is impacted by the environment (niche) of these cells. Satellite cell function is affected by oxidative stress, which is elevated in aged muscles, and this along with changes in largely unknown systemic factors, likely contribute to the manner in which satellite cells respond to stressors such as exercise, disuse, or rehabilitation in sarcopenic muscles. Nutritional intervention provides one therapeutic strategy to improve the satellite cell niche and systemic factors, with the goal of improving satellite cell function in aging muscles. Although many elderly persons consume various nutraceuticals with the hope of improving health, most of these compounds have not been thoroughly tested, and the impacts that they might have on sarcopenia and satellite cell function are not clear. This review discusses data pertaining to the satellite cell responses and function in aging skeletal muscle, and the impact that three compounds: resveratrol, green tea catechins, and $\beta$-Hydroxy- $\beta$-methylbutyrate have on regulating satellite cell function and therefore contributing to reducing sarcopenia or improving muscle mass after disuse in aging. The data suggest that these nutraceutical compounds improve satellite cell function during rehabilitative loading in animal models of aging after disuse (i.e., muscle regeneration). While these compounds have not been rigorously tested in humans, the data from animal models of aging provide a strong basis for conducting additional focused work to determine if these or other nutraceuticals can offset the muscle losses, or improve regeneration in sarcopenic muscles of older humans via improving satellite cell function.

Keywords: aging, oxidative stress, apoptosis, rehabilitation, injury, disuse atrophy

\section{INTRODUCTION}

Sarcopenia is the age-associated reduction in muscle mass and function (Evans, 1995; Kim and Choi, 2013), which is particularly severe after the seventh decade of life (Dutta et al., 1997). Sarcopenia increases the susceptibility to muscle injury (Faulkner et al., 1995), serious falls (Tinetti, 2001), obesity (Stenholm et al., 2008), and diabetes (Kim et al., 2010; Ghosh et al., 2014). Furthermore, the deleterious effects of extended muscle disuse (e.g., prolonged bed rest in the elderly) on muscle mass, strength, and function is exacerbated with sarcopenia (Suetta et al., 2009; Marzetti et al., 2010; Hao et al., 2011; Calvani et al., 2013; Alway et al., 2014a). As a result, it is important to identify strategies that could slow or reverse sarcopenia. One area that has attracted recent attention is the area of myogenic stem cells or satellite cells, as a means to improve regeneration of old muscles and to offset the negative consequences of sarcopenia.

\section{MECHANISMS THAT MAY CONTRIBUTE TO SARCOPENIA AND LOWER THE ABILITY TO REVERSE ATROPHY IN AGING}

To mount an effective therapeutic strategy to treat sarcopenia, it becomes necessary to understand the components that contribute to this pathogenesis. While the mechanisms responsible for sarcopenia are not well understood, there are likely several factors that contribute to muscle loss in aging. These include but may not be limited to: reduced protein synthesis (Dickinson et al., 2013;
Churchward-Venne et al., 2014), declines in neural function (Drey et al., 2013; Kwan, 2013; Mosole et al., 2014), hormonal deficits (Michalakis et al., 2013), chronic inflammation (Lee et al., 2007; Degens, 2010; Mavros et al., 2014), oxidative stress (Hiona and Leeuwenburgh, 2008; Jackson et al., 2010; Armand et al., 2011; Marzetti et al., 2013; Sullivan-Gunn and Lewandowski, 2013), loss of mitochondrial function (Chabi et al., 2008; Ljubicic et al., 2009; Calvani et al., 2013; Marzetti et al., 2013), inappropriate signaling in muscle due at least in part to inadequate nutrition (Burgos, 2012; Ghosh et al., 2014; Welch, 2014; Welch et al., 2014), nuclear apoptosis (Sjostrom et al., 1992; Alway et al., 2002, 2011; Leeuwenburgh, 2003; Dupont-Versteegden, 2005; Alway and Siu, 2008; Chabi et al., 2008), and reduced satellite cell function (Conboy and Rando, 2005; Snijders et al., 2009; Barberi et al., 2013). This review will focus on the potential impact that mediation of satellite cell function has in aging skeletal muscle.

\section{SATELLITE CELL BIOLOGY}

Satellite cells are a heterogeneous collection of adult muscle stem cells that are normally quiescent. They were first identified more than 50 years ago as a unique population of nuclei that were "sandwiched" between the sarcolemma and the basement membrane of the muscle fiber (Mauro, 1961). Utilization of unique cell surface markers and methods to identify satellite cell proliferation and differentiation have provided evidence to 
show that this cell is critically important in muscle growth and repair as well as the processes of adaptation to stresses including exercise, disease, injury, and aging. Satellite cell progression from proliferation through differentiation of their daughter cells is tightly regulated by muscle transcription factors. Adult quiescent satellite cells express the paired homeobox transcription factor Pax7 (Seale et al., 2000, 2004). Another transcription factor, Pax3, a paralog of Pax7, is also expressed in a subset of satellite cells of some but not all muscles (Relaix et al., 2006; Buckingham and Relaix, 2007; Day et al., 2007; Yablonka-Reuveni et al., 2008). Nevertheless, Pax7 appears to be necessary in satellite cells after birth as Pax7-null mice are viable but lack any functional satellite cells (Kuang et al., 2006; Seale et al., 2000; Seale et al., 2004).

Under basal conditions, adult satellite cells remain quiescent and reside (relatively) dormant within their niche adjacent to the myofiber (Schultz et al., 1978) (Figure 1). While satellite cells might be exposed to the changing cellular niche, they do not become activated until a major insult or stress (e.g., exercise loading) occurs. In response to injury, satellite cells proliferate and their Pax7-positive daughter cells either differentiate, by migrating through the sarcolemma and fusing with existing muscle fibers (Figure 1) during the growth and regeneration of muscle (Moss and Leblond, 1971; von et al., 2013), or they commit to a program of self-renew (Schmalbruch and Lewis, 2000; Collins et al., 2005). Myogenic regulator factor (MRF) genes provide myogenic specificity for activated satellite cells. The MRFs include myogenic differentiation 1 protein (MyoD), myogenic factor 5 (Myf5), myogenin, and muscle-specific regulatory factor 4 (Mrf4). Myf5 and/or MyoD expression are quickly increased at the point of satellite cell activation (Cornelison and Wold, 1997). Pax7 regulates Myf5 and MyoD expression levels (Parise et al., 2008; Rudnicki et al., 2008) in satellite cells. It is necessary for Pax7 to be down-regulated prior to terminal differentiation of the satellite cell derived daughter cells (Olguin and Olwin, 2004; Olguin et al., 2007). The satellite cell pool is repopulated by the fraction of activated satellite cells that maintain a high level of Pax7.

A number of studies using different Pax7 ablation strategies in mouse muscles, have clearly shown that satellite cells are indispensable for muscle regeneration (Lepper et al., 2011; Murphy et al., 2011; Sambasivan et al., 2011). Furthermore, when satellite cells are absent, injured skeletal muscle does not regenerate or regenerate very poorly in response to muscle injury (Seale and Rudnicki, 2000; Seale et al., 2000; Oustanina et al., 2004; Kuang et al., 2006). To make it worse, inflammatory and adipogenic cells replace injured regions of contractile tissue in muscles from Pax7-null animals (Sambasivan et al., 2011), and the increase in non-contractile tissue in repair or growth in the absence of Pax7 decreases the specific tension (force per cross sectional area) potential in skeletal muscle (Fry et al., 2014). It is also important to note that non-myogenic stem cells are unable to repair the injured muscle, suggesting that satellite cells are essential for skeletal muscle regeneration (Sambasivan et al., 2011). Furthermore, while some muscle hypertrophy that is induced via overload appears possible in the absence of

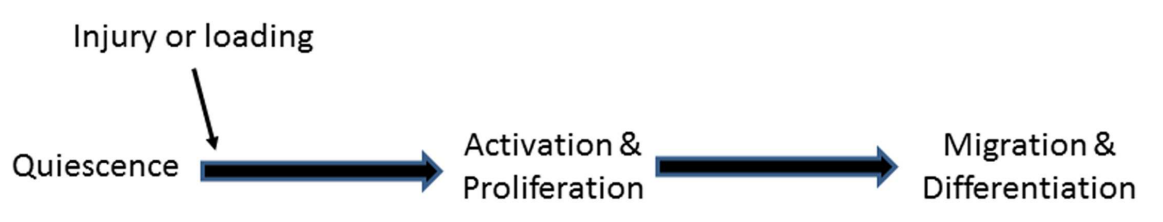

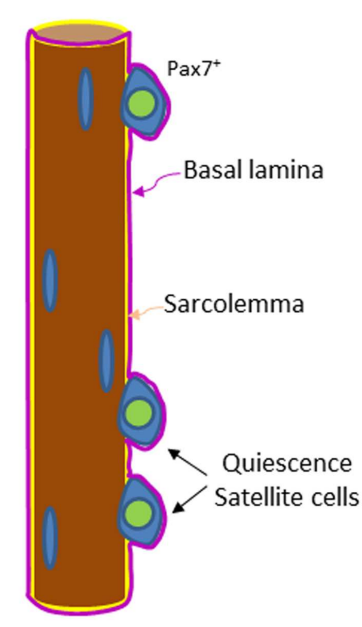

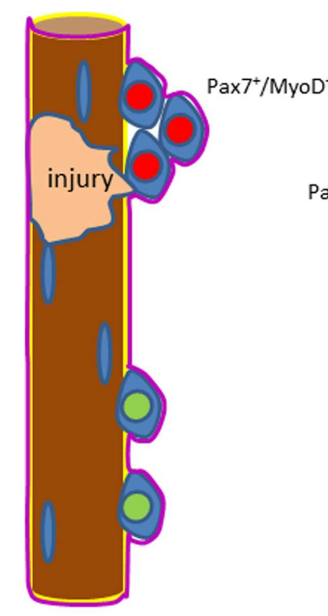

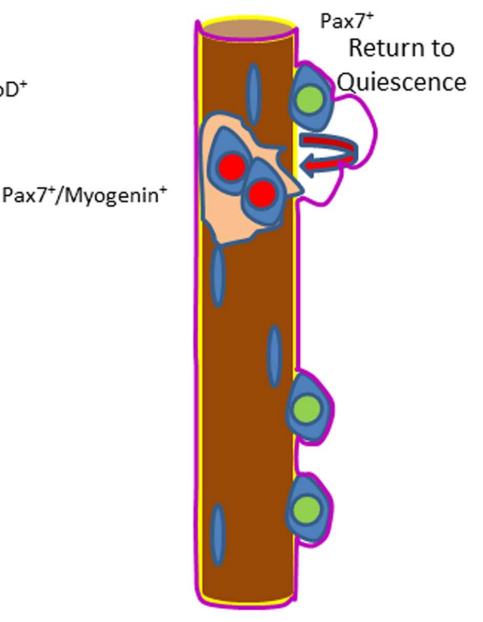

FIGURE 1 | Illustration of the activation and the differentiation of satellite cells in muscles of young or old hosts. Satellite cells are positioned anatomically between the basal lamina (purple) and the sarcolemma (yellow). Satellite cells express Pax7 in the quiescent (green) state. Upon injury or loading, satellite cells are activated and proliferate (red) and express Pax7 followed by both Pax7 and MyoD. Some of the proliferated daughter cells from the original satellite cells leave their position and pass through the sarcolemma and migrate to the site of injury, where they fuse with the existing fiber and engage in fiber repair and/or contribute to fiber growth/hypertrophy. In aging and sarcopenic muscles, satellite cell proliferation and/or differentiation may be impaired, which contribute to a lower regenerative potential. 
satellite cells, long-term muscle adaptation to overload is diminished, as seen by smaller muscle fibers and a lower muscle mass and muscle strength. Thus, satellite cells are important not only in muscle repair but also in regulating muscle adaptations to hypertrophic growth (Fry et al., 2014). Thus, it is possible, or even likely that a diminished function in satellite cells plays an important role in mediating the long-term muscle reductions with sarcopenia.

\section{SATELLITE CELL FUNCTION IN AGING}

The potential mechanisms involved in the reduction of skeletal muscle mass during sarcopenia converge on satellite cells, and together they contribute to failure of satellite cells to replace and repair damaged muscle fibers (Jang et al., 2011; Garcia-Prat et al., 2013; Wang et al., 2013; Sousa-Victor et al., 2014). The lower regenerative potential of aged muscles is correlated nicely with the decline in satellite cell function (Jang et al., 2011; Chakkalakal and Brack, 2012; Collins-Hooper et al., 2012; Bernet et al., 2014) and a reduction in the Pax7 pool of myogenic stem cells (Collins et al., 2007). For example, the proliferation and differentiation potentials of satellite cells in both mammals and non-mammals are reduced with increasing age (Bortoli et al., 2005; Velleman et al., 2010; Barberi et al., 2013; Harthan et al., 2013). In addition, recent evidence by Sousa-Victor et al. (2014) suggest that a large portion of the aged (geriatric) satellite cells switch from the reversible quiescent state to a senescence state, which prevents proliferation and renewal of the satellite cell pool. Thus, this loss of satellite cell function likely contributes strongly to the reduced ability to repair or replace muscle that is lost in sarcopenia. Although satellite cells in the aged niche are not proliferative, they do express Sprouty1 (spry1), an inhibitor of fibroblast growth factor (FGF) signaling (Chakkalakal et al., 2012). It is thought that increasing FGF signaling in aged satellite cells under basal conditions by down regulating spry 1 would result in a loss of quiescence (Chakkalakal et al., 2012). Thus, aged satellite cells may actively promote quiescence through regulating spry 1 in their own niche, thereby making it more difficult to activate these cells for growth or repair.

Moreover, satellite cell content has been reported to decrease in muscles of old humans and animals as compared to their younger counter parts (Day et al., 2010; Verdijk et al., 2012, 2014). Furthermore, there is evidence that a decline in satellite cell number contributes to muscle fiber atrophy (Brack et al., 2005). Nevertheless, some studies have not found a loss of satellite cells in old muscles as compared to muscles from young animals (van der Meer et al., 2011b), but this is complicated by the fact that although muscle mass/bodyweight was lower in the old animals, the absolute muscle mass was similar in young and old animals.

Whether satellite cell number is lost or not, it appears more clear that satellite cell function is reduced in aging. However, it is likely that an important cause for reduced satellite cell function in aging may be a result of altered systemic factors that influence and/or regulate satellite cell activity and differentiation. Notably, important observations from Rando and colleagues using parabiotic pairs have shown that the regenerative potential of satellite cells can be improved in muscles from aged mice that share the circulation with young mice (Conboy and Rando, 2005; Conboy et al., 2005). Reductions in Notch signaling in muscles of aged rodents lead to a reduced satellite cell proliferation and an inability to produce myoblasts in response to muscle injury. In addition, restoring circulating levels of protein growth differentiation factor 11 (GDF11) in old mice has recently been shown to improve satellite cell and muscle function (Sinha et al., 2014). Other factors contributing to sarcopenia potentially through their actions on satellite cells could involve reduced IGF-I (Harridge, 2003), inflammation and pro-inflammatory cytokines (Degens, 2010), and altered muscle metabolism (Jang et al., 2011).

Although satellite cells appear to have important roles in regeneration of old or young muscles, their involvement in regulating muscle mass in response to atrophic or hypertrophic stimuli is quite complex. For example, rapid muscle loss occurring from denervation has been reported to result in a transient increase in satellite cells in muscles of old rats within 1 week after denervation (van der Meer et al., 2011b), presumably in an attempt to improve the transcriptional control of muscle proteins during this rapid period of atrophy. However, satellite cell numbers then decreased in old muscle in subsequent denervation from 2 to 4 weeks (although satellite cells/muscle cross sectional area were constant during this time) (van der Meer et al., 2011b). In contrast, muscles in young animals had an increase in satellite cell numbers over 4 weeks of denervation (van der Meer et al., 2011b), yet the increase in satellite cell numbers was unable to prevent muscle atrophy (van der Meer et al., 2011b). Clearly, there are age-induced differences in the responses of satellite cells to this atrophy stimulus by denervation, yet simply having the potential for greater transcriptional control by having more satellite cells and their daughter cells, fails to prevent the rapid muscle fiber atrophy caused by denervation.

The role that satellite cell number has in muscle growth is also complex. For example, there is evidence that at least some degree of hypertrophy can occur without the prerequisite to activate satellite cells to add new nuclei (McCarthy et al., 2011; van der Meer et al., 2011a; Jackson et al., 2012); however, larger fibers in old muscles appear to add more nuclei than smaller fibers in young animals to maintain a relatively constant nuclear domain size (van der Meer et al., 2011b), and more nuclei improve the potential for greater transcriptional control to presumably sustain their new larger muscle fiber size (Carson and Alway, 1996; Alway et al., 2003; van der Meer et al., 2011a). In addition, the extent of hypertrophy is suppressed in models where satellite cells are absent (Fry et al., 2014). Thus, satellite cells may have an important role in long-term modulating of muscle fiber size, but at least in some models of muscle wasting, increases in myonuclear number does not guarantee greater fiber sizes in denervation, and losses in satellite cells over time, follows, and does not determine, the reductions in muscle fiber size (van der Meer et al., 2011a,b). Nevertheless, it is clear that hypertrophic adaptations are suppressed when satellite cells are eliminated, and therefore, it is likely that satellite cells have a complex modulating effect on muscle mass, and in doing so, impacts muscle function. In addition, we would expect that loss of satellite cells or reduced satellite cell function by whatever means, would diminish the ability for aging muscle to both hypertrophy in response to a growth stimulus, and repair in response to an injury. Clearly, this area requires more work to fully understand the complex nature and responses of satellite cells in muscle remodeling in aging. 


\section{MODULATORS OF SATELLITE CELLS IN SARCOPENIA METABOLIC REGULATION OF SATELLITE CELL FUNCTION}

Metabolic regulators of the satellite cell niche are likely to be important modulators of satellite cell function. One potential mediator is Sirtuin 1 (Sirt1), a NAD ${ }^{+}$deacetylase that is activated by caloric restriction (Cohen et al., 2004) and resveratrol (Chen et al., 2009; Price et al., 2012), a compound found in abundance in grape skins and red wine. Sirtl also works in concert with a number of transcription factors to exert a mostly catabolic effect in cellular metabolism. One subset of these activated transcription factors is the peroxisome proliferator-activated receptor (PPAR) family (Lin et al., 2005), including PPAR $\gamma$ co-activator $1 \alpha(\mathrm{PGC} 1 \alpha)$. PGC1 $\alpha$ is a transcriptional co-activator and a major regulator of mitochondrial biogenesis and metabolism (Spiegelman, 2007; Stepto et al., 2012). In muscle and other cell types, PGC1 $\alpha$ regulates the activity of PPAR alpha (PPAR $\alpha$ ) and PPAR delta (PPAR $\delta)$. PPAR $\alpha$, is expressed in the heart, liver, and skeletal muscle, regulates mitochondrial biogenesis and fatty acid uptake and oxidation. PPAR $\delta$ is expressed in the intestines, liver, and skeletal muscle but notably, experiments that have eliminated PPAR $\delta$ in muscle, have reported a decreased level of satellite cell proliferation, leading to reduced muscle regenerative capacity after injury, further establishing its link to satellite cell function (Angione et al., 2011). PGC1 $\alpha$ induced mitochondrial biogenesis appears to be an important component that regulates satellite cell function in regenerating muscle following injury (Duguez et al., 2002). Supporting this finding, short-term caloric restriction has been found to increase satellite cell proliferation in young and old mice, presumably through a Sirt1-PGC1 $\alpha$ mechanism (Cerletti et al., 2012). Furthermore, alterations in PGC1 $\alpha$ through Sirt1 have been shown to reduce satellite cell-induced muscle regeneration during conditions of muscle wasting (Toledo et al., 2011). Thus, there appears to be a clear link between mitochondrial biogenesis/function and satellite cell function, and increasing mitochondrial function increases satellite cell proliferation in muscle regeneration (Jash and Adhya, 2012). However, the mechanisms that mediate this interaction are less clear and the impact that altering mitochondrial-mediated metabolic function will have on satellite cell function in muscles of old animals is less well known. Furthermore, it is not known if mitochondrially induced satellite cell modulation is fiber-type specific in aged muscles.

\section{MITOCHONDRIAL FUNCTION AND OXIDATIVE STRESS REGULATE SATELLITE CELL FUNCTION IN AGING}

In addition to metabolic function, mitochondria are key producers of reactive oxygen species (ROS). A low level of ROS is thought to be an important regulator of several cell signal transduction pathways in a variety of cellular functions including muscle (Frey et al., 2006, 2009; Powers et al., 2011). However, excessive ROS levels are believed to be key initiators and mediators of dysfunction in a variety of cells including muscle cells. This includes ROS mediated disruptions in cell signaling, metabolism, transcriptional activity, mitochondrial function, and increased activation of apoptotic pathways (Allen and Tresini, 2000; Marzetti et al., 2013; SullivanGunn and Lewandowski, 2013). For example, aging is associated with excessive ROS levels, which increases mitochondrial damage, and in turn, contributes to mitochondrially mediated apoptotic signaling (Barberi et al., 2013; Bennett et al., 2013; Szczesny et al., 2013; Vasilaki and Jackson, 2013). This suggests that mitochondria might produce high ROS levels in muscle and in activated satellite cells, and this could contribute to impaired satellite cell function (or initiate pathways that could result in satellite cell death). However, this relationship is complex because human muscle satellite cells that were isolated from elderly human vastus lateralis muscles have reduced mitochondrial mass, and lower whole cell ATP levels, but when they were stimulated maximally, they appeared to have normal mitochondrial ATP production, increased mitochondrial membrane potential, and increased superoxide/mitochondrial mass and hydrogen peroxide/mitochondrial mass ratios (Minet and Gaster, 2012). These data suggest that although ROS production was higher in isolated satellite cells from aged muscles, there was not a marked reduction in mitochondrial function of the remaining mitochondria (Minet and Gaster, 2012). Nevertheless, the high basal levels of ROS may provide an unfavorable environment, which can adversely affect satellite cell function and limit muscle repair in aging. One of the possible causes that could exacerbate the effects of ROS on satellite cell function is the decline the antioxidative capacity and the increasing ROS levels of skeletal muscle with increasing age, which diminish satellite cell function (Beccafico et al., 2007). Moreover, the antioxidant activity of catalase and glutathione transferase is reduced in satellite cells derived from elderly subjects as compared to satellite cells isolated from young individuals (Fulle et al., 2005). It is likely that the elevated basal levels of ROS in the satellite cell niche could induce oxidative damage to the quiescent satellite cells, and this damage could negatively affect the satellite cells' ability to repair aging muscle when they become activated (Fulle et al., 2005).

An alternative negative effect of high ROS levels in aging muscles may be to drive the normal myogenic phenotype of activated satellite cells to that of an adipogenic phenotype. Such a muscle-tofat transition and satellite cell behavior could explain the increase in inter-muscular adipose deposits that are characterized with many metabolic diseases as well as sarcopenia (Rice et al., 1989; Vettor et al., 2009).

\section{EXERCISE REGULATION OF SATELLITE CELLS IN AGING MUSCLE}

Although exercise or loading can partially rescue the reduction in satellite cell function (Dreyer et al., 2006; Snijders et al., 2009; Verdijk et al., 2009; Shefer et al., 2010), muscle fibers typically do not hypertrophy to the same extent in old animals as compared to young animals, even if the young and old animals receive the same stimulus and this is at least partially attributable to agingsuppressed satellite cell function (Carson et al., 1995; Carson and Alway, 1996; Lowe et al., 1998; Cutlip et al., 2006). Thus, while full reversal of sarcopenia does not appear to be possible, exercise, and overload nevertheless, have been used as a rehabilitative tool to compensate for sarcopenia, and can at least partially reverse the age-imposed decrements in performance. Nevertheless, experiments that have examined the exercise- and loading-associated reduction in muscle mass function in humans, rats, and other animal models of aging, have produced varied results from modest to poor reversal of sarcopenia. For example, 30 days of identical loading conditions resulted in $44 \%$ greater muscle mass in youngadult birds, but only an increase in muscle mass of $25 \%$ in aged 
quails (Carson and Alway, 1996). In addition, 14 days of functional overload in the rat plantaris muscle increases muscle weight by $25 \%$ in young-adult animals but only by $9 \%$ in old rats (Alway et al., 2002, 2005). Furthermore, 28 days of electrical stimulationinduced contractions caused muscle hypertrophy and improved function in young rat dorsi flexor muscles, but no improvement in muscle force or mass were found in old animals (Cutlip et al., 2006; Murlasits et al., 2006).

It is clear that loading types of exercise have profound effects on satellite cell function in muscles of young hosts, largely through activation of various growth factors and cytokines, resulting in increases in muscle protein synthesis, and net muscle protein accretion (Phillips et al., 1997). Furthermore, activation of satellite cells occurs as part of the modulation of exercise-induced adaptation even in acute responses to loading exercise where hypertrophy has not occurred (Joanisse et al., 2013). Specifically, growth factors such as insulin like growth factor-I (IGF1) (McKay et al., 2008), interleukin-6 (IL-6) cytokine induced signal transducer, and activator of transcription 3 (STAT3) signaling have been shown to occur exclusively in human satellite cells, including their proliferation in response to exercise-induced lengthening injury (Toth et al., 2011). Furthermore, non-injurious running exercise has been shown to increase Wnt signaling and that activation of the canonical $\mathrm{Wnt} / \beta$-catenin signaling pathway increased the expression of Myf5 and MyoD in satellite cells (Fujimaki et al., 2014). However, given the greater senescent phenotype of satellite cells in aged muscles (Sousa-Victor et al., 2014), it seems likely that exercise would have a greater challenge for activating satellite cells in aged sarcopenic muscles as compared to young-adult muscles. Nevertheless, while aging decreases the satellite cell content in type II fibers of humans (Verdijk et al., 2014), aging appears to delay but not eliminate the activation of satellite cells in muscles of elderly men in response to acute resistance exercise (Snijders et al., 2014a; Verdijk et al., 2014).

While an age-associated reduction in growth differentiation factor 11 (GDF11) has been shown, a recent report indicates that restoring systemic levels of GDF11 in aged muscle improved not only satellite cell derived muscle repair but increased muscle strength, mass, and endurance in aged mice (Sinha et al., 2014). This shows the potential for important interactions between circulating factors and exercise-induced satellite cell function; however, it would seem that exercise alone, without the pharmacological intervention and interaction is insufficient to reverse all of the aging-associated satellite cell function in sarcopenia. Although electrically evoked contractions are not exact duplications of voluntary exercise, most of the cellular signaling pathways are similar whether the contractions are voluntary or evoked. Thus, it is interesting to note that electrically evoked contractions in muscles of elderly subjects, increased the proliferation of satellite cells as indicated by a greater number of N-CAM and Pax7-expressing cells (surface markers of satellite cells), and also increased IGF-I and myostatin, which, were thought to loosely represent markers in the pathway for satellite cell differentiation (Kern et al., 2014). Thus, exercise and models that simulate exercise have profound effects on satellite cell function in aging muscles. One of the challenges in muscle biology is to identify targets and strategies that are likely to maximize the positive benefits of exercise on satellite cell function with the goal to reduce or offset sarcopenia.

\section{DISUSE REDUCES SATELLITE CELL NUMBER IN AGING}

Disuse atrophy is caused by mechanical unloading of muscle and this leads to reduced muscle mass. Frequently used models of unloading in humans include casting/immobilization, and a sedentary lifestyle (inactivity), and in rodents, hindlimb suspension, immobilization, and denervation are typically used as models of disuse. Satellite cells are fundamentally involved in skeletal muscle responses to environmental changes that induce atrophy. The area that surrounds the satellite cell (niche) plays an important role in the fate and function of satellite cells (Bentzinger et al., 2013), and therefore, it is not surprising that changes in the muscle environment that occur during disuse can affect the satellite cell niche.

Several studies report that conditions of disuse lead to an elevation in the number of nuclei that have been targeted for apoptosis both inside and outside myofibers (Allen et al., 1997; Vescovo et al., 1998, 2000; Siu and Alway, 2009; Alway et al., 2011; Hao et al., 2011). However, other studies have failed to find a change in myonuclei number with atrophy, and loss of satellite cells during disuse is not a consistent finding. For example, satellite cell number appeared to be quite stable after acute disuse including 14 days of immobilization in young healthy men (Snijders et al., 2014b), or 28 days of bed rest in middle aged men (Brooks et al., 2010), whereas in another study, 14 days of immobilization resulted in a loss of satellite cells in older humans (Suetta et al., 2013). Severe disuse atrophy as characterized by spinal cord injury has been reported to result in lower satellite cell numbers in both type I and type II fibers (Verdijk et al., 2012). Furthermore, sarcopenia is accompanied by a loss of satellite cells, particularly in type II fibers (Verdijk et al., 2012, 2014) although the reductions in both fiber size and satellite cell number occur relatively slowly. In contrast, rapid declines in muscle mass do not correlate closely with satellite cell numbers (van der Meer et al., 2011b). Nevertheless, satellite cells may have an important role in long-term modulating of muscle fiber size including disuse atrophy, and sarcopenia, but there is evidence to suggest that such changes in myonuclear number may not determine the immediate changes in muscle fiber size (van der Meer et al., 2011a,b). Nevertheless, the age of the host and the severity or type of disuse, likely helps to determine whether satellite cells survive, the time course of any changes in satellite cell number, or how they are able to respond to additional stressors.

Although proliferation of satellite cells is critical to muscle regeneration after an injury, proliferation of satellite cells without adequate differentiation does not improve muscle mass. For example, acute satellite cell proliferation has been reported in response to spinal muscular atrophy-induced muscle denervation (Martinez-Hernandez et al., 2014) presumably as an attempt to increase the nuclear population for elevating transcriptional signaling, yet, the atrophy signaling predominates the muscle, and the net result is that denervated muscles become smaller, even with an acute increase in satellite cells. Thus, effective strategies to combat sarcopenia and accelerated muscle loss in aging should evaluate the effects of interventions on both proliferation and differentiation of satellite cells and their daughter cells. 


\section{MODULATION OF SATELLITE CELL FUNCTION IN SARCOPENIA VIA NUTRACEUTICALS}

It is clear that the nutritional status of a host affects the potential for satellite cell proliferation and differentiation to occur (Halevy et al., 2000; Powell et al., 2013, 2014; Harthan et al., 2014). For example, food restriction in birds post-hatch has been shown to reduce muscle mass accumulation with increased fat deposition and necrosis (Velleman et al., 2010) as a result of a decrease in satellite cell mitotic activity (Mozdziak et al., 2002; Halevy et al., 2003). However, the mechanisms by which nutritional interventions regulate satellite cell function are less well defined. One possibility is that the systemic diffusion of nutritional compounds and nutraceuticals from the blood (presumably diffusion from capillaries throughout the muscle) changes the satellite cell environment or "niche." The area that is enclosed between the basal lamina and sarcolemma of a muscle fiber houses the satellite cell, but this same space provides an insulated environment in which the satellite cell exists (Lander et al., 2012; Bentzinger et al., 2013; Montarras et al., 2013). Presumably this niche maintains the satellite cells in a quiescent state. It is likely that the metabolic milieu of the satellite cell niche differs from the muscle fiber and/or the extracellular space that surrounds the fibers. Although speculative, it is possible that nutraceuticals diffuse from the systemic circulation (i.e., capillaries) and pass through the basal lamina membrane barrier to the satellite cell niche to change its metabolic composition. This idea would be consistent with the hypothesis that satellite cell function can be regulated via changes to the niche environment (Cosgrove et al., 2009; Chakkalakal and Brack, 2012; Chakkalakal et al., 2012; Gilbert et al., 2012). Although it is not clear if the nutraceuticals can directly activate satellite cells to move them from a quiescent to an active state, it is clear that if they have begun a proliferative cycle, that several nutraceuticals can enhance their function in responses to various stimuli superimposed on sarcopenia. However, the evidence suggests that diffusion of the nutraceutical into the satellite cell niche could "prime" the satellite cell, so that once it experienced the appropriate chemical and/or mechanical and/or electrical signals for proliferation, would increase the extent of proliferation in these cells (Hao et al., 2011; Ryan et al., 2011; Alway et al., 2013; Bennett et al., 2013).

It is further feasible that nutraceuticals can act indirectly on satellite cells by modulating or directly suppressing the effects of ROS, or increasing antioxidant production. Either of these possibilities would result in lowering the impact of ROS damage on satellite cells.

Another possibility is that rather than affecting the satellite cell niche, the nutraceutical modulates satellite cell behavior after these cells have left their niche, or perhaps the niche environment is lost because the basal lamina or sarcolemma has been damaged. In this scenario, the cellular milieu containing the nutraceutical mixes with the satellite cell niche and then promotes enhanced proliferation of activated satellite cells. Again this could occur from a direct effect on satellite cells (e.g., epigenetic changes to satellite cells) and/or indirectly via suppressing the effects of ROS on satellite cells. Future studies are required to determine which nutritional interventions change the contents of the satellite cell niche, or if rather, the nutraceuticals have a direct effect on satellite cells that is independent from the niche environment.
In addition to the local satellite cell niche milieu, satellite cell function appears to have an interaction with the fiber that it is attached to. There are more satellite cells that are associated with fibers that are predominantly oxidative (slow, type I fibers), as compared with fibers that rely primarily on glycolysis (fast, type II fibers) (Schmalbruch and Hellhammer, 1977; Putman et al., 2001; Brack et al., 2005; Christov et al., 2007). Nutraceuticals may have differential effects on satellite cells in predominately type II vs. type I fibers. For example, proliferation of satellite cells was increased in plantaris (predominately type II fibers) muscles from old rats that were reloaded after hindlimb suspension following treatment with HMB (Alway et al., 2013) or EGCg (Alway et al., 2014a), whereas satellite cells were elevated in both plantaris and soleus (predominately type I fibers) muscles of old rats that were treated with green tea extract under these conditions (Alway et al., 2014b). As nutraceutical treatments do not appear to have a marked impact on slowing accelerated muscle wasting in sarcopenia (Table 1), but instead appears to be more effective in rehabilitating muscles after a period of disuse (Table 2), we suspect that this treatment strategy modulates and does not activate the satellite cells, as we would not anticipate a high level of satellite cell proliferation during periods of long-term disuse.

It is not known if the nutraceutical mediated improvement in satellite cell proliferation especially during rehabilitative efforts in sarcopenic muscle, was due to direct signaling from the fiber to the satellite cell niche or the satellite cells themselves, and it is not known how the satellite cell niche, fiber type, or extracellular matrix signaling might influence satellite cell function in response to skeletal muscle regeneration or hypertrophic growth in sarcopenic muscles from old hosts. These questions should be the focus of future studies as this information will be helpful in planning strategies that might improve muscle repair and slow the progression of sarcopenia. Furthermore, understanding the effect of nutraceuticals on satellite cells in a fiber-type specific fashion is important, because the satellite cells in fast muscles appear to be more vulnerable to dysfunction in aging and show a reduction in total satellite cell numbers (Verdijk et al., 2007, 2014) as compared to satellite cells associated with type I fibers. Nevertheless, while slow oxidative muscles seem to be better preserved than the fast fibers in sarcopenic muscles (Deschenes et al., 2013; Purves-Smith et al., 2014), the impact of nutraceuticals on type I fiber associated satellite cells should not be ignored, because this preservation of type I fiber size and function might be lost in the very old, when sarcopenia becomes very severe (Purves-Smith et al., 2014).

\section{RESVERATROL}

\section{Resveratrol and satellite cell function}

Within the past decade, sirtuin 1 (Sirt1), a $\mathrm{NAD}^{+}$dependent deacetylase, has been identified as an important metabolic regulator of skeletal muscle gene expression (Fulco et al., 2003). Specifically, elevated Sirt1 activity has been shown to increase proliferation of satellite cells (Rathbone et al., 2009). Furthermore, Sirtl has been reported to inhibit the differentiation of mouse C2C12 myoblasts (an in vitro model of activated satellite cells), and reduce the expression of myogenin an important regulator for satellite cell (daughter cell) differentiation (Fulco et al., 2003; Vinciguerra et al., 2010). This suggests that Sirt1 could have a role 
Table 1 | Summary of nutraceutical effect on apoptosis and muscle function in aging muscle during forced disuse

\begin{tabular}{|c|c|c|c|c|c|c|}
\hline Nutraceutical & Treatment & Apoptotic signaling & Fiber area & Muscle mass & Maximal force & Reference \\
\hline $\mathrm{EGCg}$ & HLS & $\downarrow(25-30 \%)$ & $\uparrow(21 \%)$ & $\rightarrow$ & $\rightarrow$ & Alway et al. (2014a) \\
\hline Resveratrol & HLS & $\rightarrow$ & $\rightarrow$ & $\rightarrow$ & ND & Bennett et al. (2013) \\
\hline Green Tea Catechins & HLS & ND & ND & $\rightarrow$ & $\uparrow(10 \%)$ & Ota et al. (2011) \\
\hline
\end{tabular}

The arrow indicates the increase $(p \leq 0.05)$, decrease $(p \leq 0.05)$, or no difference $(p \geq 0.05)$ between the vehicle vs. nutraceutical. The percent difference from vehicle treatment is indicated in parenthesis.

Table 2 | Summary of nutraceutical effect on satellite cell function, apoptosis and muscle function in growing/regenerating aged muscle

\begin{tabular}{|c|c|c|c|c|c|c|c|}
\hline Nutraceutical & Treatment & $\begin{array}{l}\text { Satellite cell } \\
\text { proliferation }\end{array}$ & $\begin{array}{l}\text { Apoptotic } \\
\text { signaling }\end{array}$ & $\begin{array}{l}\text { Muscle } \\
\text { mass }\end{array}$ & Fiber area & $\begin{array}{l}\text { Maximal } \\
\text { force }\end{array}$ & Reference \\
\hline $\mathrm{HMB}$ & Reloading after HLS & $\uparrow(3 \%)$ & ND & $\uparrow(6 \%)$ & $\uparrow(12 \%)$ & $\rightarrow$ & Alway et al. (2013) \\
\hline $\mathrm{HMB}$ & Cell culture & $\uparrow(250 \%)$ & $\downarrow(30-70 \%)$ & ND & ND & ND & Kornasio et al. (2009) \\
\hline EGCg & Reloading after HLS & $\uparrow(3 \%)$ & $\downarrow(23-50 \%)$ & $\uparrow(14 \%)$ & $\uparrow(36 \%)$ & $\uparrow(20 \%)$ & Alway et al. (2014a) \\
\hline Resveratrol & Aging & ND & $\rightarrow$ & $\rightarrow$ & ND & $\rightarrow$ & Jackson et al. (2011) \\
\hline Resveratrol & Reloading after HLS & $\rightarrow$ & $\downarrow(0-29 \%)$ & $\uparrow(10 \%)$ & $\uparrow(28-45 \%)$ & ND & Bennett et al. (2013) \\
\hline
\end{tabular}

The arrow indicates the increase $(p \leq 0.05)$, decrease $(p \leq 0.05)$, or no difference $(p \geq 0.05)$ between the vehicle vs. nutraceutical. The percent difference from vehicle treatment is indicated in parenthesis).

of delaying differentiation and therefore prolonging or enhancing proliferation of satellite cells in response to a growth stimulus. Furthermore, reduced nutrient availability inhibits $\mathrm{C} 2 \mathrm{C} 12$ myoblast differentiation in a Sirtl dependent manner (Fulco et al., 2008). Interestingly, the $\mathrm{NAD}^{+}$salvage enzyme nicotinamide phosphoribosyltransferase was found to mediate the effects of nutrient (glucose) deprivation on myogenic differentiation in vitro (Fulco et al., 2008). However, to this point, it is not clear if Sirt1 has a direct or an indirect role in mediating satellite cell proliferation or differentiation in vivo in aged/sarcopenic muscles. Nevertheless, we have some clues through other nutritional based intervention studies that suggest that resveratrol, through Sirt1 has a direct effect on regulating satellite cell function in aging. For example, resveratrol, a Sirtl activator that was given to old rats during a period of recovery following hindlimb suspension had a modest improvement in satellite cell proliferation in hindlimb muscles in response to cage ambulation that followed period of muscle disuse as compared to a vehicle control treatment (Bennett et al., 2013). It is also possible that resveratrol has multiple effects in aged muscles. For example, it appears to also have a more profound protective effect in aging by buffering high levels of oxidative stress which is amplified in old animals during periods of muscle disuse or loading (Jackson et al., 2010; Ryan et al., 2010; Joseph et al., 2013; Durbin et al., 2014). Furthermore, although a constant long-term consumption of resveratrol does not eliminate sarcopenia (Jackson et al., 2011), it is possible that increasing the dose of resveratrol as the animal ages, to better counter the increasing ROS accumulation (and ROS increases with greater age) might have had a different outcome. Nevertheless, together the data suggest that resveratrol might lower excessively high ROS levels, and this would be expected to improve satellite cell function and/or prevent loss of some of the activated satellite cells in responses to stressors (e.g., loading), that otherwise might be lost (destroyed) in a very high ROS environment such as aging and loading, although it probably has modest effects on quiescent satellite cells that are attached to sarcopenic muscles. It is noteworthy that increased levels of Sirtl have been reported in satellite cells isolated from old rats, although the significance of this is not clear (Machida and Booth, 2004). Thus, it is possible that when Sirt1 was elevated in satellite cells of old animals, it may not have been active and therefore unable to produce the anticipated benefits that have been associated with Sirt1 in aged muscles. This is likely because activated Sirt1 has been shown to directly induce proliferation of satellite cells (Rathbone et al., 2009).

\section{Resveratrol - a link to inflammation mediated satellite cell function?} In addition to its role in metabolism-regulation of satellite cells, resveratrol, through Sirtl deacetylates and activates PGC1 $\alpha$, which in turn activates transcription factors like the farsenoid $\mathrm{x}$ receptor (FXR), PPAR $\alpha$, and PPAR $\delta$, which have anti-inflammatory effects (Galuppo et al., 2010; Xu et al., 2012). Thus, it is possible that PGC1 $\alpha$ 's role in muscle regeneration may be to signal the end of the inflammation period and begin the period of regeneration (satellite cell proliferation and/or differentiation). 
Though the role of inflammation in muscle regeneration is currently unclear, the current thought is that early inflammation inhibits muscle regeneration, so that necrotic and damaged cells may be cleared from the injury site, while the later response, such as the arrival of macrophages, has a stimulating effect on muscle repair. Furthermore, macrophages increase the proliferation rate of satellite cells, while depletion of macrophages after a muscle injury has been shown to inhibit satellite cell function to reduce the rate of muscle regeneration (Tidball, 2005; Tidball and Wehling-Henricks, 2007). Thus, understanding PGC1 $\alpha$ 's connection to inflammation (Westerbacka et al., 2007) and regulation of mitochondrial biogenesis and satellite cell function through resveratrol or other nutraceuticals, may help to further elucidate its role in the inflammatory response period that is associated with muscle regeneration in aging.

\section{EPIGALLOCATECHIN GALLATE AND SATELLITE CELLS}

One of the most abundant catechins in green tea is epigallocatechin-3-gallate (EGCg), which has strong antioxidant and anti-inflammatory properties. EGCg is believed to be responsible for most of the health benefits linked to green tea. Both disuse and reloading which accelerate muscle loss in sarcopenia, greatly increase the oxidative stress in the affected muscles of old animals (Andrianjafiniony et al., 2010; Jackson et al., 2010; Pellegrino et al., 2011). Reducing the high basal levels of oxidative stress in aging could potentially attenuate muscle mass decrement that occurs in response to disuse conditions and/or improve muscle recovery during reloading after disuse in aging (Jackson et al., 2010). Recent data suggest that oxidative stress is reduced both in cultured cells (Casanova et al., 2014) and after eccentric exercise upon supplementation with green tea catechins (Haramizu et al., 2011). Furthermore, green tea catechins reduce the decrement in soleus muscle force during a period of hindlimb suspension in mice (Ota et al., 2011). In addition, EGCg has been shown to reduce protein degradation in culture (Mirza et al., 2014). We have recently shown that activation of satellite cells as shown by labeling with the thymidine analog 5-bromo-2-deoxyuridine (BrdU), was significantly greater in reloaded muscles of old rats after a 14 days of hindlimb suspension muscle disuse as compared to muscles from vehicle-treated old animals (Alway et al., 2014a). Interestingly, this appeared to be a fiber or muscle-specific effect on satellite cell proliferation, because while 14 days of reloading increased BrdU labeled nuclei in the plantaris from EGCg treated muscles (7.4\%) compared to vehicle-treated animals (6.3\%), EGCg did not improve satellite cell activation in the soleus muscle of reloaded animals. Using green tea extract that contained approximately $50 \%$ EGCg, we found that satellite cell proliferation and differentiation of the satellite cell daughter cells were both increased in muscles of old rats during reloading after 14 days of hindlimb suspension (Alway et al., 2014b). Moreover, data from old mice and humans that were fed EGCg for 7 days, showed improved markers for satellite cell activation (Myf5, MyoD) (Gutierrez-Salmean et al., 2014). However, EGCg treatment also reduced anabolic suppressor proteins (e.g., myostatin) (Gutierrez-Salmean et al., 2014), so it is more difficult to tell if EGCg provides a direct or indirect effect on satellite cell function. Nevertheless, together these results show that EGCg and perhaps other catechins contained in green tea were effective in improving satellite cell proliferation. We speculate that having more available satellite cell derived daughter nuclei supported the adaptation for greater muscle cross sectional area and this improved the recovery of muscle mass following disuse in sarcopenic rat muscles (Alway et al., 2014a).

\section{HMB REGULATION OF SATELLITE CELLS IN SARCOPENIA}

The leucine metabolite, $\beta$-hydroxy- $\beta$-methylbutyrate (HMB) has been shown to improve satellite cell proliferation (Moore et al., 2005), reduce protein catabolism during disease, reduce muscle loss during disuse, and promote skeletal muscle hypertrophy in response to loading exercise (Wilson et al., 2008; Holecek et al., 2009; Aversa et al., 2011). We have previously shown that HMB could improve muscle recovery in old rats with sarcopenia that had been subjected to unloading, in part via an increase in satellite cell proliferation and a reduction of nuclear apoptosis (Hao et al., 2011). HMB also has been shown to have direct effects on proliferation of myoblasts in vitro (Kornasio et al., 2009), although, its efficacy on satellite cell activation has not previously been evaluated in vivo in aged immobilized animals. We found that HMB-treatment in old rats during reloading after forced disuse resulted in a significantly greater $(p<0.01)$ level of BrdU positive satellite cells in plantaris muscle cross sections of aged HMBtreated animals $(9.1 \%$ of total myonuclei) as compared to the animals in the vehicle group $(6.1 \%$ of total myonuclei) (Alway et al., 2013). This was confirmed by a greater percentage of $\mathrm{Pax}^{+}$ and $\mathrm{MyoD}^{+}$myonuclei (derived from satellite cells) relative to the total myonuclear pool in reloaded plantaris muscles as compared to reloaded muscles from vehicle-treated old animals (Alway et al., 2013). Thus, the mechanism of action through which HMB is responsible for enhancing muscle recovery following extended disuse in sarcopenic muscles of old rats appears to be at least in part, via increased proliferation of muscle satellite cells in fast twitch plantaris muscles of aged animals. However, the enhancement of satellite cell proliferation by $\mathrm{HMB}$ is not a universal finding. For example, older women who were fed HMB for six days during a period of resistance training to load their skeletal muscles had a $\sim 100 \%$ increase in satellite cell numbers, but HMB did not increase satellite cell proliferation further over resistance training alone (Kim et al., 2012). Additional work is needed to determine if the beneficial effects of HMB on satellite cell function will be observed in older humans if the dose or duration of HMB is altered.

\section{REGULATION OF NUCLEAR DEATH SIGNALS BY NUTRACEUTICALS}

Satellite cells that are isolated from sarcopenic muscles from old rodents and humans have a greater propensity for apoptosis and greater levels of apoptotic signaling proteins (Fulle et al., 2012, 2013). Not only can apoptosis signaling target mature post mitotic nuclei for elimination, but satellite cells and their daughter cells that are activated as part of a hypertrophic adaptation to a loading stimulus, can be targets for elimination as well (Alway and Siu, 2008). Satellite cell number decreases with increased aging (Snow, 1977; Verdijk et al., 2014), and one possibility to explain this reduction in satellite cells is due to an increased susceptibility to nuclear apoptosis in aging and therefore, this may contribute to sarcopenia (Leeuwenburgh, 2003; Pistilli et al., 2006; Adhihetty et al., 2008, 


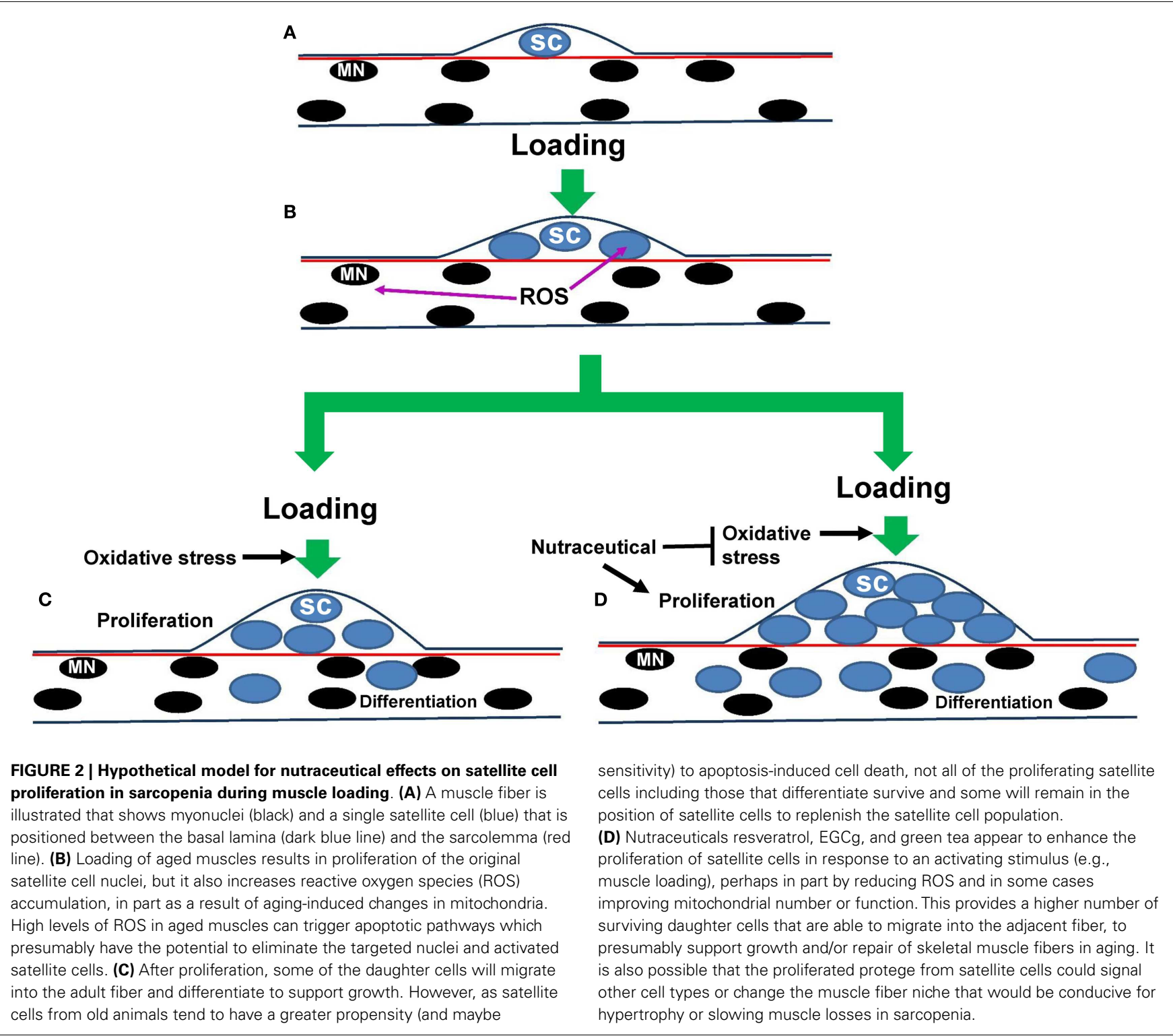

2009; Ljubicic et al., 2009; Alway et al., 2011; Quadrilatero et al., 2011; Marzetti et al., 2012; Calvani et al., 2013). Furthermore, the pro-apoptotic protein Bax, is increased in satellite cells of old rats (Krajnak et al., 2006) and this leads to accelerated muscle loss in sarcopenic muscles via apoptosis (Dupont-Versteegden et al., 2006; Pistilli et al., 2006; Alway et al., 2014a). However, signaling for apoptosis is reduced and more satellite cells (e.g., Pax $7 / \mathrm{MyoD}^{+}$ cells) survive during rehabilitation after disuse in aged rat muscles that are treated with HMB (Hao et al., 2011; Alway et al., 2013), EGCg (Alway et al., 2014a), or green tea catechins (Alway et al., 2014b) as compared to a control treatment. In contrast, resveratrol fed animals had lower levels of oxidative stress, but only modest changes in apoptotic signaling (Jackson et al., 2010; Bennett et al., 2013) as compared to control animals. Although the mechanism(s) by which nutraceuticals impact satellite cell function, including reducing pro-apoptotic targeting of satellite cells, is likely to be complex. Part of the improvement in apoptotic signaling in activated satellite cells may be due to an upregulation of antioxidants and a reduction of oxidative stress and/or inflammation after nutraceutical treatments including resveratrol (Jackson et al. 2010, 2011; Ryan et al., 2010) and green tea catechins (Ota et al., 2011; Wang et al., 2011; Andrade and Assuncao, 2012; Wu et al., 2012; Haramizu et al., 2013). Given the propensity for apoptosis to occur in satellite cells isolated from old hosts including humans (Fulle et al., 2012, 2013), further investigations into the potential for nutraceuticals to improve satellite cell function in aging are warranted. Together these data support the idea that reducing the systemic (and perhaps also the satellite cell niche) signaling for apoptosis, may promote better survival of satellite cells and their daughter cells in muscles of old animals, and this may contribute to improved muscle recovery after periods of disuse (e.g., hospitalization) and reduce the effects of sarcopenia in the elderly. 


\section{CONCLUSION}

Although the satellite cell has been identified and studied for more than a half of a century (Mauro, 1961), there is still much that we do not know about this unique muscle stem cell in aging. In general, there is a reduction in satellite cell number and function that occurs with aging, especially in type II fibers, but this does not seem to be due to increased DNA damage in these cells (Cousin et al., 2013). Nevertheless, it is clear that satellite cell proliferation and differentiation contributes to a greater myonuclear pool. Improving satellite cell proliferation occurs especially in fast muscles of aged animals provided supplemental HMB, EGCg, resveratrol or green tea, and a greater number of satellite cell derived nuclei should provide a greater potential for transcriptional and translational control for improving regeneration in aged muscles (Figure 2). One possibility is that the nutraceuticals act to buffer the high levels of ROS in aging muscles of old animals. Nutraceuticals may also reduce the level of oxidative stress that is elevated in aging muscles in response to loading or disuse. The less oxidative environment may encourage the survival of more of the activated satellite cells so that they can participate in muscle repair. Additionally, as EGCg has been shown to improve muscle function following a nerve crush injury (Renno et al., 2012), it would be interesting to know in future studies if catechins or other nutraceuticals could delay or suppress age-associated denervation. Furthermore, nutritionally regulated reductions in the potential for death signals (e.g., apoptosis) to eliminate satellite cell progeny that have migrated inside a muscle fiber should also improve the potential for transcriptional and translational regulation of muscle fiber regeneration or repair in aging. Thus, nutraceuticals appear to have the potential to regulate satellite cell function, and in doing so, impact skeletal muscle regeneration, particularly during rehabilitative efforts that follow a period of disuse in aged animals (Table 2). Unfortunately, nutraceuticals do not appear to have profound effects on slowing accelerated loss in sarcopenic muscles (Table $\mathbf{1}$ ).

Clinical trials in humans are warranted to determine if these or other nutraceuticals, will similarly improve muscle recovery following bed rest or other conditions of muscle loss in aging as observed in rodents. However, it has only been recent that we have begun to appreciate the potential links between nutrition and metabolism and satellite cell function in health and disease. In the context of treating sarcopenia, it is important to note that not all changes in diet that might slow muscle loss, necessarily affect satellite cell function. For example, dietary protein intake alone does not modulate the post-exercise increase in satellite cell content but instead, it modifies myostatin expression in skeletal muscle tissue, which contributes to the increase in protein accretion after acute exercise (Snijders et al., 2014a). Thus, it is important to distinguish between satellite cell and non-satellite cell functions of nutraceuticals in sarcopenic muscles of the aging hosts. Understanding the nutritional regulation of satellite cell function appears to be a potentially promising avenue for identifying strategies to reduce muscle wasting in sarcopenia, and to improve the recovery of muscle that is lost during a period of disuse in aged humans.

\section{REFERENCES}

Adhihetty, P. J., O’Leary, M. F., and Hood, D. A. (2008). Mitochondria in skeletal muscle: adaptable rheostats of apoptotic susceptibility. Exerc. Sport Sci. Rev. 36, 116-121. doi:10.1097/JES.0b013e31817be7b7
Adhihetty, P. J., Uguccioni, G., Leick, L., Hidalgo, J., Pilegaard, H., and Hood, D. A. (2009). The role of PGC-1\{alpha\} on mitochondrial function and apoptotic susceptibility in muscle. Am. J. Physiol. Cell Physiol. 297, C217-C225. doi:10.1152/ajpcell.00070.2009

Allen, D. L., Linderman, J. K., Roy, R. R., Bigbee, A. J., Grindeland, R. E., Mukku, V., et al. (1997). Apoptosis: a mechanism contributing to remodeling of skeletal muscle in response to hindlimb unweighting. Am. J. Physiol. 273(2 Pt 1), C579-C587.

Allen, R. G., and Tresini, M. (2000). Oxidative stress and gene regulation. Free Radic. Biol. Med. 28, 463-499. doi:10.1016/S0891-5849(99)00242-7

Alway, S. E., Bennett, B. T., Wilson, J. C., Edens, N. K., and Pereira, S. L. (2014a). Epigallocatechin-3-gallate improves plantaris muscle recovery after disuse in aged rats. Exp. Gerontol. 50, 82-94. doi:10.1016/j.exger.2013.11.011

Alway, S. E., Bennett, B. T., Wilson, J. C., Sperringer, J., Mohamed, J. S., Edens, N. K., et al. (2014b). Green tea extract attenuates muscle loss and improves muscle function during disuse and increases satellite cell proliferation during reloading after hindlimb suspension in aged rodents. J. Appl. Physiol. (in press).

Alway, S. E., Degens, H., Lowe, D. A., and Krishnamurthy, G. (2002). Increased myogenic repressor Id mRNA and protein levels in hindlimb muscles of aged rats. Am. J. Physiol. Regul. Integr. Comp. Physiol. 282, R411-R422. doi:10.1152/ ajpregu.00332.2001

Alway, S. E., Martyn, J. K., Ouyang, J., Chaudhrai, A., and Murlasits, Z. S. (2003). Id2 expression during apoptosis and satellite cell activation in unloaded and loaded quail skeletal muscles. Am. J. Physiol. Regul. Integr. Comp. Physiol. 284, R540-R549. doi:10.1152/ajpregu.00550.2002

Alway, S. E., Morissette, M. R., and Siu, P. M. (2011). "Aging and apoptosis in muscle," in Handbook of the Biology of Aging, eds E. J. Masoro and S. Austad (Amsterdam: Elsevier), 64-139.

Alway, S. E., Pereira, S. L., Edens, N. K., Hao, Y., and Bennett, B. T. (2013). $\beta$ Hydroxy- $\beta$-methylbutyrate (HMB) enhances the proliferation of satellite cells in fast muscles of aged rats during recovery from disuse atrophy. Exp. Gerontol. 48, 973-984. doi:10.1016/j.exger.2013.06.005

Alway, S. E., and Siu, P. M. (2008). Nuclear apoptosis contributes to sarcopenia. Exerc. Sport Sci. Rev. 36, 51-57. doi:10.1097/JES.0b013e318168e9dc

Alway, S. E., Siu, P. M., Murlasits, Z., and Butler, D. C. (2005). Muscle hypertrophy models: applications for research on aging. Can. J. Appl. Physiol. 30, 591-624. doi:10.1139/h05-143

Andrade, J. P., and Assuncao, M. (2012). Protective effects of chronic green tea consumption on age-related neurodegeneration. Curr. Pharm. Des. 18, 4-14. doi:10.2174/138161212798918986

Andrianjafiniony, T., Dupre-Aucouturier, S., Letexier, D., Couchoux, H., and Desplanches, D. (2010). Oxidative stress, apoptosis, and proteolysis in skeletal muscle repair after unloading. Am. J. Physiol. Cell Physiol. 299, C307-C315. doi:10.1152/ajpcell.00069.2010

Angione, A. R., Jiang, C., Pan, D., Wang, Y. X., and Kuang, S. (2011). PPARdelta regulates satellite cell proliferation and skeletal muscle regeneration. Skelet. Muscle 1, 33. doi:10.1186/2044-5040-1-33

Armand, A. S., Laziz, I., Djeghloul, D., Lecolle, S., Bertrand, A. T., Biondi, O., et al. (2011). Apoptosis-inducing factor regulates skeletal muscle progenitor cell number and muscle phenotype. PLoS ONE 6:e27283. doi:10.1371/journal.pone. 0027283

Aversa, Z., Bonetto, A., Costelli, P., Minero, V. G., Penna, F., Baccino, F. M., et al. (2011). Beta-hydroxy-beta-methylbutyrate (HMB) attenuates muscle and body weight loss in experimental cancer cachexia. Int. J. Oncol. 38, 713-720. doi:10.3892/ijo.2010.885

Barberi, L., Scicchitano, B. M., De Rossi, M., Bigot, A., Duguez, S., Wielgosik, A., et al. (2013). Age-dependent alteration in muscle regeneration: the critical role of tissue niche. Biogerontology 14, 273-292. doi:10.1007/s10522-013-9429-4

Beccafico, S., Puglielli, C., Pietrangelo, T., Bellomo, R., Fano, G., and Fulle, S. (2007). Age-dependent effects on functional aspects in human satellite cells. Ann. N. Y. Acad. Sci. 1100, 345-352. doi:10.1196/annals.1395.037

Bennett, B. T., Mohamed, J. S., and Alway, S. E. (2013). Effects of resveratrol on the recovery of muscle mass following disuse in the plantaris muscle of aged rats. PLoS ONE 8:e83518. doi:10.1371/journal.pone.0083518

Bentzinger, C. F., Wang, Y. X., Dumont, N. A., and Rudnicki, M. A. (2013). Cellular dynamics in the muscle satellite cell niche. EMBO Rep. 14, 1062-1072. doi:10.1038/embor.2013.182

Bernet, J. D., Doles, J. D., Hall, J. K., Kelly, T. K., Carter, T. A., and Olwin, B. B. (2014). p38 MAPK signaling underlies a cell-autonomous loss of stem cell self-renewal in skeletal muscle of aged mice. Nat. Med. 20, 265-271. doi:10.1038/nm.3465 
Bortoli, S., Renault, V., Mariage-Samson, R., Eveno, E., Auffray, C., Butler-Browne, G., et al. (2005). Modifications in the myogenic program induced by in vivo and in vitro aging. Gene 347, 65-72. doi:10.1016/j.gene.2004.12.029

Brack, A. S., Bildsoe, H., and Hughes, S. M. (2005). Evidence that satellite cell decrement contributes to preferential decline in nuclear number from large fibres during murine age-related muscle atrophy. J. Cell Sci. 118, 4813-4821. doi: $10.1242 /$ jcs. 02602

Brooks, N. E., Cadena, S. M., Vannier, E., Cloutier, G., Carambula, S., Myburgh, K. H., et al. (2010). Effects of resistance exercise combined with essential amino acid supplementation and energy deficit on markers of skeletal muscle atrophy and regeneration during bed rest and active recovery. Muscle Nerve 42, 927-935. doi: $10.1002 /$ mus. 21780

Buckingham, M., and Relaix, F. (2007). The role of Pax genes in the development of tissues and organs: Pax3 and Pax7 regulate muscle progenitor cell functions. Annu. Rev. Cell Dev. Biol. 23, 645-673. doi:10.1146/annurev.cellbio.23.090506. 123438

Burgos, P. R. (2012). Therapeutic approach to malnutrition and sarcopenia. Nestle Nutr. Inst. Workshop Ser. 72, 85-99. doi:10.1159/000339995

Calvani, R., Joseph, A. M., Adhihetty, P. J., Miccheli, A., Bossola, M., Leeuwenburgh, C., et al. (2013). Mitochondrial pathways in sarcopenia of aging and disuse muscle atrophy. Biol. Chem. 394, 393-414. doi:10.1515/hsz-2012-0247

Carson, J. A., and Alway, S. E. (1996). Stretch overload-induced satellite cell activation in slow tonic muscle from adult and aged Japanese quail. Am. J. Physiol. 270, C578-C584.

Carson, J. A., Yamaguchi, M., and Alway, S. E. (1995). Hypertrophy and proliferation of skeletal muscle fibers from aged quail. J. Appl. Physiol. 78, 293-299.

Casanova, E., Baselga-Escudero, L., Ribas-Latre, A., Arola-Arnal, A., Blade, C., Arola, L., et al. (2014). Epigallocatechin gallate counteracts oxidative stress in docosahexaenoxic acid-treated myocytes. Biochim. Biophys. Acta 1837, 783-791. doi:10.1016/j.bbabio.2014.01.014

Cerletti, M., Jang, Y. C., Finley, L. W., Haigis, M. C., and Wagers, A. J. (2012). Shortterm calorie restriction enhances skeletal muscle stem cell function. Cell Stem Cell 10, 515-519. doi:10.1016/j.stem.2012.04.002

Chabi, B., Ljubicic, V., Menzies, K. J., Huang, J. H., Saleem, A., and Hood, D. A. (2008). Mitochondrial function and apoptotic susceptibility in aging skeletal muscle. Aging Cell 7, 2-12. doi:10.1111/j.1474-9726.2007.00347.x

Chakkalakal, J., and Brack, A. (2012). Extrinsic regulation of satellite cell function and muscle regeneration capacity during aging. J. Stem Cell Res. Ther. S11, 001. doi:10.4172/2157-7633.S11-001

Chakkalakal, J. V., Jones, K. M., Basson, M. A., and Brack, A. S. (2012). The aged niche disrupts muscle stem cell quiescence. Nature 490, 355-360. doi:10.1038/ nature 11438

Chen, C. J., Yu, W., Fu, Y. C., Wang, X., Li, J. L., and Wang, W. (2009). Resveratrol protects cardiomyocytes from hypoxia-induced apoptosis through the SIRT1FoxO1 pathway. Biochem. Biophys. Res. Commun. 378, 389-393. doi:10.1016/j. bbrc.2008.11.110

Christov, C., Chretien, F., Abou-Khalil, R., Bassez, G., Vallet, G., Authier, F. J., et al. (2007). Muscle satellite cells and endothelial cells: close neighbors and privileged partners. Mol. Biol. Cell 18, 1397-1409. doi:10.1091/mbc.E06-08-0693

Churchward-Venne, T. A., Breen, L., and Phillips, S. M. (2014). Alterations in human muscle protein metabolism with aging: protein and exercise as countermeasures to offset sarcopenia. Biofactors 40, 199-205. doi:10.1002/biof.1138

Cohen, H. Y., Miller, C., Bitterman, K. J., Wall, N. R., Hekking, B., Kessler, B., et al. (2004). Calorie restriction promotes mammalian cell survival by inducing the SIRT1 deacetylase. Science 305, 390-392. doi:10.1126/science.1099196

Collins, C. A., Olsen, I., Zammit, P. S., Heslop, L., Petrie, A., Partridge, T. A., et al. (2005). Stem cell function, self-renewal, and behavioral heterogeneity of cells from the adult muscle satellite cell niche. Cell 122, 289-301. doi:10.1016/j.cell. 2005.05.010

Collins, C. A., Zammit, P. S., Ruiz, A. P., Morgan, J. E., and Partridge, T. A. (2007). A population of myogenic stem cells that survives skeletal muscle aging. Stem Cells 25, 885-894. doi:10.1634/stemcells.2006-0372

Collins-Hooper, H., Woolley, T. E., Dyson, L., Patel, A., Potter, P., Baker, R. E., et al. (2012). Age-related changes in speed and mechanism of adult skeletal muscle stem cell migration. Stem Cells 30, 1182-1195. doi:10.1002/stem.1088

Conboy, I. M., Conboy, M. J., Wagers, A. J., Girma, E. R., Weissman, I. L., and Rando, T. A. (2005). Rejuvenation of aged progenitor cells by exposure to a young systemic environment. Nature 433, 760-764. doi:10.1038/nature03260
Conboy, I. M., and Rando, T. A. (2005). Aging, stem cells and tissue regeneration: lessons from muscle. Cell Cycle 4, 407-410. doi:10.4161/cc.4.3.1518

Cornelison, D. D., and Wold, B. J. (1997). Single-cell analysis of regulatory gene expression in quiescent and activated mouse skeletal muscle satellite cells. Dev. Biol. 191, 270-283. doi:10.1006/dbio.1997.8721

Cosgrove, B. D., Sacco, A., Gilbert, P. M., and Blau, H. M. (2009). A home away from home: challenges and opportunities in engineering in vitro muscle satellite cell niches. Differentiation 78, 185-194. doi:10.1016/j.diff.2009.08.004

Cousin, W., Ho, M. L., Desai, R., Tham, A., Chen, R. Y., Kung, S., et al. (2013). Regenerative capacity of old muscle stem cells declines without significant accumulation of DNA damage. PLoS ONE 8:e63528. doi:10.1371/journal.pone. 0063528

Cutlip, R. G., Baker, B. A., Geronilla, K. B., Mercer, R. R., Kashon, M. L., Miller, G. R., et al. (2006). Chronic exposure to stretch-shortening contractions results in skeletal muscle adaptation in young rats and maladaptation in old rats. Appl. Physiol. Nutr. Metab. 31, 573-587. doi:10.1139/h06-033

Day, K., Shefer, G., Richardson, J. B., Enikolopov, G., and Yablonka-Reuveni, Z. (2007). Nestin-GFP reporter expression defines the quiescent state of skeletal muscle satellite cells. Dev. Biol. 304, 246-259. doi:10.1016/j.ydbio.2006.12.026

Day, K., Shefer, G., Shearer, A., and Yablonka-Reuveni, Z. (2010). The depletion of skeletal muscle satellite cells with age is concomitant with reduced capacity of single progenitors to produce reserve progeny. Dev. Biol. 340, 330-343. doi:10.1016/j.ydbio.2010.01.006

Degens, H. (2010). The role of systemic inflammation in age-related muscle weakness and wasting. Scand. J. Med. Sci. Sports 20, 28-38. doi:10.1111/j.1600-0838. 2009.01018.x

Deschenes, M. R., Gaertner, J. R., and O’Reilly, S. (2013). The effects of sarcopenia on muscles with different recruitment patterns and myofiber profiles. Curr. Aging Sci. 6, 266-272. doi:10.2174/18746098113066660035

Dickinson, J. M., Volpi, E., and Rasmussen, B. B. (2013). Exercise and nutrition to target protein synthesis impairments in aging skeletal muscle. Exerc. Sport Sci. Rev. 41, 216-223. doi:10.1097/JES.0b013e3182a4e699

Drey, M., Grosch, C., Neuwirth, C., Bauer, J. M., and Sieber, C. C. (2013). The motor unit number index (MUNIX) in sarcopenic patients. Exp. Gerontol. 48, 381-384. doi:10.1016/j.exger.2013.01.011

Dreyer, H. C., Blanco, C. E., Sattler, F. R., Schroeder, E. T., and Wiswell, R. A. (2006). Satellite cell numbers in young and older men 24 hours after eccentric exercise. Muscle Nerve 33, 242-253. doi:10.1002/mus.20461

Duguez, S., Feasson, L., Denis, C., and Freyssenet, D. (2002). Mitochondrial biogenesis during skeletal muscle regeneration. Am. J. Physiol. Endocrinol. Metab. 282, E802-E809. doi:10.1152/ajpendo.00343.2001

Dupont-Versteegden, E. E. (2005). Apoptosis in muscle atrophy: relevance to sarcopenia. Exp. Gerontol. 40, 473-481. doi:10.1016/j.exger.2005.04.003

Dupont-Versteegden, E. E., Strotman, B. A., Gurley, C. M., Gaddy, D., Knox, M., Fluckey, J. D., et al. (2006). Nuclear translocation of EndoG at the initiation of disuse muscle atrophy and apoptosis is specific to myonuclei. Am. J. Physiol. Regul. Integr. Comp. Physiol. 291, R1730-R1740. doi:10.1152/ajpregu. 00176.2006

Durbin, S. M., Jackson, J. R., Ryan, M. J., Gigliotti, J. C., Alway, S. E., and Tou, J. C. (2014). Resveratrol supplementation preserves long bone mass, microstructure and strength in hindlimb-suspended old male rats. J. Bone Miner. Metab. 32 38-47. doi:10.1007/s00774-013-0469-2

Dutta, C., Hadley, E. C., and Lexell, J. (1997). Sarcopenia and physical performance in old age: overview. Muscle Nerve Suppl. 5, S5-S9. doi:10.1002/(SICI)10974598(1997)5+<5::AID-MUS2>3.3.CO;2-D

Evans, W. J. (1995). What is sarcopenia? J. Gerontol. A Biol. Sci. Med. Sci. 50 Spec No, 5-8. doi:10.1093/gerona/50A.Special_Issue.5

Faulkner, J. A., Brooks, S. V., and Zerba, E. (1995). Muscle atrophy and weakness with aging: contraction-induced injury as an underlying mechanism. J. Gerontol. A Biol. Sci. Med. Sci. 50 Spec No, 124-129.

Frey, R. S., Gao, X., Javaid, K., Siddiqui, S. S., Rahman, A., and Malik, A. B. (2006). Phosphatidylinositol 3-kinase gamma signaling through protein kinase Czeta induces NADPH oxidase-mediated oxidant generation and NF-kappaB activation in endothelial cells. J. Biol. Chem. 281, 16128-16138. doi:10.1074/jbc. M508810200

Frey, R. S., Ushio-Fukai, M., and Malik, A. B. (2009). NADPH oxidase-dependent signaling in endothelial cells: role in physiology and pathophysiology. Antioxid. Redox Signal. 11, 791-810. doi:10.1089/ARS.2008.2220 
Fry, C. S., Lee, J. D., Jackson, J. R., Kirby, T. J., Stasko, S. A., Liu, H., et al. (2014). Regulation of the muscle fiber microenvironment by activated satellite cells during hypertrophy. FASEB J. 28, 1654-1665. doi:10.1096/fj.13-239426

Fujimaki, S., Hidaka, R., Asashima, M., Takemasa, T., and Kuwabara, T. (2014). Wnt protein-mediated satellite cell conversion in adult and aged mice following voluntary wheel running. J. Biol. Chem. 289, 7399-7412. doi:10.1074/jbc.M113. 539247

Fulco, M., Cen, Y., Zhao, P., Hoffman, E. P., McBurney, M. W., Sauve, A. A., et al. (2008). Glucose restriction inhibits skeletal myoblast differentiation by activating SIRT1 through AMPK-mediated regulation of Nampt. Dev. Cell 14, 661-673. doi:10.1016/j.devcel.2008.02.004

Fulco, M., Schiltz, R. L., Iezzi, S., King, M. T., Zhao, P., Kashiwaya, Y., et al. (2003). Sir2 regulates skeletal muscle differentiation as a potential sensor of the redox state. Mol. Cell 12, 51-62. doi:10.1016/S1097-2765(03)00226-0

Fulle, S., Centurione, L., Mancinelli, R., Sancilio, S., Manzoli, F. A., and Di, P. R. (2012). Stem cell ageing and apoptosis. Curr. Pharm. Des. 18, 1694-1717. doi:10.2174/138161212799859657

Fulle, S., Di Donna, S., Puglielli, C., Pietrangelo, T., Beccafico, S., Bellomo, R., et al. (2005). Age-dependent imbalance of the antioxidative system in human satellite cells. Exp. Gerontol. 40, 189-197. doi:10.1016/j.exger.2004.11.006

Fulle, S., Sancilio, S., Mancinelli, R., Gatta, V., and Di Pietro, R. (2013). Dual role of the caspase enzymes in satellite cells from aged and young subjects. Cell Death Dis. 4, e955. doi:10.1038/cddis.2013.472

Galuppo, M., Di Paola, R., Mazzon, E., Genovese, T., Crisafulli, C., Paterniti, I. et al. (2010). Role of PPAR-delta in the development of zymosan-induced multiple organ failure: an experiment mice study. J. Inflamm. (Lond.) 7, 12. doi:10.1186/1476-9255-7-12

Garcia-Prat, L., Sousa-Victor, P., and Munoz-Canoves, P. (2013). Functional dysregulation of stem cells during aging: a focus on skeletal muscle stem cells. FEBS J. 280, 4051-4062. doi:10.1111/febs.12221

Ghosh, S., Lertwattanarak, R., Garduno, J. D., Galeana, J. J., Li, J., Zamarripa, F., et al. (2014). Elevated muscle TLR4 expression and metabolic endotoxemia in human aging. J. Gerontol. A Biol. Sci. Med. Sci. doi:10.1093/gerona/glu067

Gilbert, P. M., Corbel, S., Doyonnas, R., Havenstrite, K., Magnusson, K. E., and Blau, H. M. (2012). A single cell bioengineering approach to elucidate mechanisms of adult stem cell self-renewal. Integr. Biol. (Camb.) 4, 360-367. doi:10.1039/c2ib00148a

Gutierrez-Salmean, G., Ciaraldi, T. P., Nogueira, L., Barboza, J., Taub, P. R., Hogan, M. C., et al. (2014). Effects of (-)-epicatechin on molecular modulators of skeletal muscle growth and differentiation. J. Nutr. Biochem. 25, 91-94. doi:10.1016/j.jnutbio.2013.09.007

Halevy, O., Geyra, A., Barak, M., Uni, Z., and Sklan, D. (2000). Early posthatch starvation decreases satellite cell proliferation and skeletal muscle growth in chicks. J. Nutr. 130, 858-864.

Halevy, O., Nadel, Y., Barak, M., Rozenboim, I., and Sklan, D. (2003). Early posthatch feeding stimulates satellite cell proliferation and skeletal muscle growth in turkey poults. J. Nutr. 133, 1376-1382.

Hao, Y., Jackson, J. R., Wang, Y., Edens, N., Pereira, S. L., and Alway, S. E. (2011). $\beta$-Hydroxy- $\beta$-methylbutyrate reduces myonuclear apoptosis during recovery from hind limb suspension-induced muscle fiber atrophy in aged rats. Am. J. Physiol. Regul. Integr. Comp. Physiol. 301, R701-R715. doi:10.1152/ajpregu. 00840.2010

Haramizu, S., Ota, N., Hase, T., and Murase, T. (2011). Catechins attenuate eccentric exercise-induced inflammation and loss of force production in muscle in senescence-accelerated mice. J. Appl. Physiol. 111, 1654-1663. doi:10.1152/ japplphysiol.01434.2010

Haramizu, S., Ota, N., Hase, T., and Murase, T. (2013). Catechins suppress muscle inflammation and hasten performance recovery after exercise. Med. Sci. Sports Exerc. 45, 1694-1702. doi:10.1249/MSS.0b013e31828de99f

Harridge, S. D. (2003). Ageing and local growth factors in muscle. Scand. J. Med. Sci. Sports 13, 34-39. doi:10.1034/j.1600-0838.2003.20235.x

Harthan, L. B., McFarland, D. C., and Velleman, S. G. (2013). The effect of syndecan-4 and glypican-1 expression on age-related changes in myogenic satellite cell proliferation, differentiation, and fibroblast growth factor 2 responsiveness. Comp. Biochem. Physiol. Part A Mol. Integr. Physiol. 166, 590-602. doi:10.1016/j.cbpa.2013.09.007

Harthan, L. B., McFarland, D. C., and Velleman, S. G. (2014). The effect of nutritional status and myogenic satellite cell age on turkey satellite cell proliferation, differentiation, and expression of myogenic transcriptional regulatory factors and heparan sulfate proteoglycans syndecan-4 and glypican-1. Poult. Sci. 93, 174-186. doi:10.3382/ps.2013-03570

Hiona, A., and Leeuwenburgh, C. (2008). The role of mitochondrial DNA mutations in aging and sarcopenia: implications for the mitochondrial vicious cycle theory of aging. Exp. Gerontol. 43, 24-33. doi:10.1016/j.exger.2007.10.001

Holecek, M., Muthny, T., Kovarik, M., and Sispera, L. (2009). Effect of beta-hydroxybeta-methylbutyrate (HMB) on protein metabolism in whole body and in selected tissues. Food Chem. Toxicol. 47, 255-259. doi:10.1016/j.fct.2008.11.021

Jackson, J. R., Mula, J., Kirby, T. J., Fry, C. S., Lee, J. D., Ubele, M. F., et al. (2012). Satellite cell depletion does not inhibit adult skeletal muscle regrowth following unloading-induced atrophy. Am. J. Physiol. Cell Physiol. 303, C854-C861. doi:10.1152/ajpcell.00207.2012

Jackson, J. R., Ryan, M. J., and Alway, S. E. (2011). Long-term supplementation with resveratrol alleviates oxidative stress but does not attenuate sarcopenia in aged mice. J. Gerontol. A Biol. Sci. Med. Sci. 66, 751-764. doi:10.1093/gerona/glr047

Jackson, J. R., Ryan, M. J., Hao, Y., and Alway, S. E. (2010). Mediation of endogenous antioxidant enzymes and apoptotic signaling by resveratrol following muscle disuse in the gastrocnemius muscles of young and old rats. Am. J. Physiol. Regul. Integr. Comp. Physiol. 299, R1572-R1581. doi:10.1152/ajpregu.00489.2010

Jang, Y. C., Sinha, M., Cerletti, M., Dall'Osso, C., and Wagers, A. J. (2011). Skeletal muscle stem cells: effects of aging and metabolism on muscle regenerative function. Cold Spring Harb. Symp. Quant. Biol. 76, 101-111. doi:10.1101/sqb.2011. 76.010652

Jash, S., and Adhya, S. (2012). Induction of muscle regeneration by RNA-mediated mitochondrial restoration. FASEB J. 26, 4187-4197. doi:10.1096/fj.11-203232

Joanisse, S., Gillen, J. B., Bellamy, L. M., McKay, B. R., Tarnopolsky, M. A., Gibala, M. J., et al. (2013). Evidence for the contribution of muscle stem cells to nonhypertrophic skeletal muscle remodeling in humans. FASEB J. 27, 4596-4605. doi:10.1096/fj.13-229799

Joseph, A. M., Malamo, A. G., Silvestre, J., Wawrzyniak, N., Carey-Love, S., Nguyen, L. M., et al. (2013). Short-term caloric restriction, resveratrol, or combined treatment regimens initiated in late-life alter mitochondrial protein expression profiles in a fiber-type specific manner in aged animals. Exp. Gerontol. 48, 858-868. doi:10.1016/j.exger.2013.05.061

Kern, H., Barberi, L., Lofler, S., Sbardella, S., Burggraf, S., Fruhmann, H., et al. (2014). Electrical stimulation counteracts muscle decline in seniors. Front. Aging Neurosci. 6:189. doi:10.3389/fnagi.2014.00189

Kim, J. S., Park, Y. M., Lee, S. R., Masad, I. S., Khamoui, A. V., Jo, E., et al. (2012). Betahydroxy-beta-methylbutyrate did not enhance high intensity resistance traininginduced improvements in myofiber dimensions and myogenic capacity in aged female rats. Mol. Cells 34, 439-448. doi:10.1007/s10059-012-0196-x

Kim, T. N., and Choi, K. M. (2013). Sarcopenia: definition, epidemiology, and pathophysiology. J. Bone Metab. 20, 1-10. doi:10.11005/jbm.2013.20.1.1

Kim, T. N., Park, M. S., Yang, S. J., Yoo, H. J., Kang, H. J., Song, W., et al. (2010). Prevalence and determinant factors of sarcopenia in patients with type 2 diabetes: the Korean Sarcopenic Obesity Study (KSOS). Diabetes Care 33, 1497-1499. doi:10.2337/dc09-2310

Kornasio, R., Riederer, I., Butler-Browne, G., Mouly, V., Uni, Z., and Halevy, O. (2009). Beta-hydroxy-beta-methylbutyrate (HMB) stimulates myogenic cell proliferation, differentiation and survival via the MAPK/ERK and PI3K/Akt pathways. Biochim. Biophys. Acta 1793, 755-763. doi:10.1016/j.bbamcr.2008.12.017

Krajnak, K., Waugh, S., Miller, R., Baker, B., Geronilla, K., Alway, S. E., et al. (2006). Proapoptotic factor Bax is increased in satellite cells in the tibialis anterior muscles of old rats. Muscle Nerve 34, 720-730. doi:10.1002/mus.20656

Kuang, S., Charge, S. B., Seale, P., Huh, M., and Rudnicki, M. A. (2006). Distinct roles for Pax7 and Pax3 in adult regenerative myogenesis. J. Cell Biol. 172, 103-113. doi:10.1083/jcb.200508001

Kwan, P. (2013). Sarcopenia: the gliogenic perspective. Mech. Ageing Dev. 134, 349-355. doi:10.1016/j.mad.2013.06.001

Lander, A. D., Kimble, J., Clevers, H., Fuchs, E., Montarras, D., Buckingham, M., et al. (2012). What does the concept of the stem cell niche really mean today? BMC Biol. 10:19. doi:10.1186/1741-7007-10-19

Lee, C. E., McArdle, A., and Griffiths, R. D. (2007). The role of hormones, cytokines and heat shock proteins during age-related muscle loss. Clin. Nutr. 26, 524-534. doi:10.1016/j.clnu.2007.05.005

Leeuwenburgh, C. (2003). Role of apoptosis in sarcopenia. J. Gerontol. A Biol. Sci. Med. Sci. 58, 999-1001. doi:10.1093/gerona/58.11.M999 
Lepper, C., Partridge, T. A., and Fan, C. M. (2011). An absolute requirement for Pax7-positive satellite cells in acute injury-induced skeletal muscle regeneration. Development 138, 3639-3646. doi:10.1242/dev.067595

Lin, J., Handschin, C., and Spiegelman, B. M. (2005). Metabolic control through the PGC-1 family of transcription coactivators. Cell Metab. 1, 361-370. doi:10.1016/ j.cmet.2005.05.004

Ljubicic, V., Joseph, A. M., Adhihetty, P. J., Huang, J. H., Saleem, A., Uguccioni, G., et al. (2009). Molecular basis for an attenuated mitochondrial adaptive plasticity in aged skeletal muscle. Aging (Albany NY) 1, 818-830.

Lowe, D. A., Lund, T., and Alway, S. E. (1998). Hypertrophy-stimulated myogenic regulatory factor mRNA increases are attenuated in fast muscle of aged quails. Am. J. Physiol. 275, C155-C162.

Machida, S., and Booth, F. W. (2004). Increased nuclear proteins in muscle satellite cells in aged animals as compared to young growing animals. Exp. Gerontol. 39, 1521-1525. doi:10.1016/j.exger.2004.08.009

Martinez-Hernandez, R., Bernal, S., Alias, L., and Tizzano, E. F. (2014). Abnormalities in early markers of muscle involvement support a delay in myogenesis in spinal muscular atrophy. J. Neuropathol. Exp. Neurol. 73, 559-567. doi:10.1097/NEN.0000000000000078

Marzetti, E., Calvani, R., Cesari, M., Buford, T. W., Lorenzi, M., Behnke, B. J., et al. (2013). Mitochondrial dysfunction and sarcopenia of aging: from signaling pathways to clinical trials. Int. J. Biochem. Cell Biol. 45, 2288-2301. doi:10.1016/j.biocel.2013.06.024

Marzetti, E., Hwang, J. C., Lees, H. A., Wohlgemuth, S. E., Dupont-Versteegden, E. E., Carter, C. S., et al. (2010). Mitochondrial death effectors: relevance to sarcopenia and disuse muscle atrophy. Biochim. Biophys. Acta 1800, 235-244. doi:10.1016/j.bbagen.2009.05.007

Marzetti, E., Lees, H. A., Manini, T. M., Buford, T. W., Aranda, J. M. Jr., Calvani, R., et al. (2012). Skeletal muscle apoptotic signaling predicts thigh muscle volume and gait speed in community-dwelling older persons: an exploratory study. PLoS ONE 7:e32829. doi:10.1371/journal.pone.0032829

Mauro, A. (1961). Satellite cell of skeletal muscle fibers. J. Biophys. Biochem. Cytol. 9, 493-495. doi:10.1083/jcb.9.2.493

Mavros, Y., Kay, S., Simpson, K. A., Baker, M. K., Wang, Y., Zhao, R. R., et al. (2014). Reductions in C-reactive protein in older adults with type 2 diabetes are related to improvements in body composition following a randomized controlled trial of resistance training. J. Cachexia Sarcopenia Muscle 5, 111-120. doi:10.1007/s13539-014-0134-1

McCarthy, J. J., Mula, J., Miyazaki, M., Erfani, R., Garrison, K., Farooqui, A. B., et al. (2011). Effective fiber hypertrophy in satellite cell-depleted skeletal muscle. Development 138, 3657-3666. doi:10.1242/dev.068858

McKay, B. R., O’Reilly, C. E., Phillips, S. M., Tarnopolsky, M. A., and Parise, G. (2008). Co-expression of IGF-1 family members with myogenic regulatory factors following acute damaging muscle-lengthening contractions in humans. J. Physiol. 586, 5549-5560. doi:10.1113/jphysiol.2008.160176

Michalakis, K., Goulis, D. G., Vazaiou, A., Mintziori, G., Polymeris, A., and Abrahamian-Michalakis, A. (2013). Obesity in the ageing man. Metab. Clin. Exp. 62, 1341-1349. doi:10.1016/j.metabol.2013.05.019

Minet, A. D., and Gaster, M. (2012). Cultured senescent myoblasts derived from human vastus lateralis exhibit normal mitochondrial ATP synthesis capacities with correlating concomitant ROS production while whole cell ATP production is decreased. Biogerontology 13, 277-285. doi:10.1007/s10522-0129372-9

Mirza, K. A., Pereira, S. L., Edens, N. K., and Tisdale, M. J. (2014). Attenuation of muscle wasting in murine CC myotubes by epigallocatechin-3-gallate. $J$. Cachexia Sarcopenia Muscle. doi:10.1007/s13539-014-0139-9

Montarras, D., L'Honore, A., and Buckingham, M. (2013). Lying low but ready for action: the quiescent muscle satellite cell. FEBS J. 280, 4036-4050. doi:10.1111/ febs. 12372

Moore, D. T., Ferket, P. R., and Mozdziak, P. E. (2005). The effect of early nutrition on satellite cell dynamics in the young turkey. Poult. Sci. 84, 748-756. doi:10.1093/ps/84.5.748

Mosole, S., Carraro, U., Kern, H., Loefler, S., Fruhmann, H., Vogelauer, M., et al. (2014). Long-term high-level exercise promotes muscle reinnervation with age. J. Neuropathol. Exp. Neurol. 73, 284-294. doi:10.1097/NEN.0000000000000032

Moss, F. P., and Leblond, C. P. (1971). Satellite cells as the source of nuclei in muscles of growing rats. Anat. Rec. 170, 421-435. doi:10.1002/ar.1091700405
Mozdziak, P. E., Walsh, T. J., and McCoy, D. W. (2002). The effect of early posthatch nutrition on satellite cell mitotic activity. Poult. Sci. 81, 1703-1708. doi:10.1093/ps/81.11.1703

Murlasits, Z., Cutlip, R. G., Geronilla, K. B., Rao, K. M., Wonderlin, W. F., and Alway, S. E. (2006). Resistance training increases heat shock protein levels in skeletal muscle of young and old rats. Exp. Gerontol. 41, 398-406. doi:10.1016/j.exger.2006.01.005

Murphy, M. M., Lawson, J. A., Mathew, S. J., Hutcheson, D. A., and Kardon, G. (2011). Satellite cells, connective tissue fibroblasts and their interactions are crucial for muscle regeneration. Development 138, 3625-3637. doi:10.1242/dev.064162

Olguin, H. C., and Olwin, B. B. (2004). Pax-7 up-regulation inhibits myogenesis and cell cycle progression in satellite cells: a potential mechanism for self-renewal. Dev. Biol. 275, 375-388. doi:10.1016/j.ydbio.2004.08.015

Olguin, H. C., Yang, Z., Tapscott, S. J., and Olwin, B. B. (2007). Reciprocal inhibition between Pax7 and muscle regulatory factors modulates myogenic cell fate determination. J. Cell Biol. 177, 769-779. doi:10.1083/jcb.200608122

Ota, N., Soga, S., Haramizu, S., Yokoi, Y., Hase, T., and Murase, T. (2011). Tea catechins prevent contractile dysfunction in unloaded murine soleus muscle: a pilot study. Nutrition 27, 955-959. doi:10.1016/j.nut.2010.10.008

Oustanina, S., Hause, G., and Braun, T. (2004). Pax7 directs postnatal renewal and propagation of myogenic satellite cells but not their specification. EMBO J. 23, 3430-3439. doi:10.1038/sj.emboj.7600346

Parise, G., McKinnell, I. W., and Rudnicki, M. A. (2008). Muscle satellite cell and atypical myogenic progenitor response following exercise. Muscle Nerve 37, 611-619. doi:10.1002/mus.20995

Pellegrino, M. A., Desaphy, J. F., Brocca, L., Pierno, S., Camerino, D. C., and Bottinelli, R. (2011). Redox homeostasis, oxidative stress and disuse muscle atrophy. J. Physiol. 589, 2147-2160. doi:10.1113/jphysiol.2010.203232

Phillips, S. M., Tipton, K. D., Aarsland, A., Wolf, S. E., and Wolfe, R. R. (1997). Mixed muscle protein synthesis and breakdown after resistance exercise in humans. Am. J. Physiol. 273, E99-E107.

Pistilli, E. E., Siu, P. M., and Alway, S. E. (2006). Molecular regulation of apoptosis in fast plantaris muscles of aged rats. J. Gerontol. A Biol. Sci. Med. Sci. 61, 245-255. doi:10.1093/gerona/61.3.245

Powell, D. J., McFarland, D. C., Cowieson, A. J., Muir, W. I., and Velleman, S. G. (2013). The effect of nutritional status on myogenic satellite cell proliferation and differentiation. Poult. Sci. 92, 2163-2173. doi:10.3382/ps.2013-03107

Powell, D. J., McFarland, D. C., Cowieson, A. J., Muir, W. I., and Velleman, S. G. (2014). The effect of nutritional status and muscle fiber type on myogenic satellite cell fate and apoptosis. Poult. Sci. 93, 163-173. doi:10.3382/ps.2013-03450

Powers, S. K., Ji, L. L., Kavazis, A. N., and Jackson, M. J. (2011). Reactive oxygen species: impact on skeletal muscle. Compr. Physiol. 1, 941-969. doi:10.1002/cphy. c100054

Price, N. L., Gomes, A. P., Ling, A. J., Duarte, F. V., Martin-Montalvo, A., North, B. J., et al. (2012). SIRT1 is required for AMPK activation and the beneficial effects of resveratrol on mitochondrial function. Cell Metab. 15, 675-690. doi:10.1016/j.cmet.2012.04.003

Purves-Smith, F. M., Sgarioto, N., and Hepple, R. T. (2014). Fiber typing in aging muscle. Exerc. Sport Sci. Rev. 42, 45-52. doi:10.1249/JES.0000000000000012

Putman, C. T., Sultan, K. R., Wassmer, T., Bamford, J. A., Skorjanc, D., and Pette, D. (2001). Fiber-type transitions and satellite cell activation in low-frequencystimulated muscles of young and aging rats. J. Gerontol. A Biol. Sci. Med. Sci. 56, B510-B519. doi:10.1093/gerona/56.12.B510

Quadrilatero, J., Alway, S. E., and Dupont-Versteegden, E. E. (2011). Skeletal muscle apoptotic response to physical activity: potential mechanisms for protection. Appl. Physiol. Nutr. Metab. 36, 608-617. doi:10.1139/h11-064

Rathbone, C. R., Booth, F. W., and Lees, S. J. (2009). Sirt1 increases skeletal muscle precursor cell proliferation. Eur. J. Cell Biol. 88, 35-44. doi:10.1016/j.ejcb.2008. 08.003

Relaix, F., Montarras, D., Zaffran, S., Gayraud-Morel, B., Rocancourt, D., Tajbakhsh, S., et al. (2006). Pax3 and Pax7 have distinct and overlapping functions in adult muscle progenitor cells. J. Cell Biol. 172, 91-102. doi:10.1083/jcb.200508044

Renno, W. M., Al-Maghrebi, M., and Al-Banaw, A. (2012). (-)-Epigallocatechin3-gallate (EGCG) attenuates functional deficits and morphological alterations by diminishing apoptotic gene overexpression in skeletal muscles after sciatic nerve crush injury. Naunyn Schmiedebergs Arch. Pharmacol. 385, 807-822. doi: $10.1007 /$ s00210-012-0758-7 
Rice, C. L., Cunningham, D. A., Paterson, D. H., and Lefcoe, M. S. (1989). Arm and leg composition determined by computed tomography in young and elderly men. Clin. Physiol. 9, 207-220. doi:10.1111/j.1475-097X.1989.tb00973.x

Rudnicki, M. A., Le, G. F., McKinnell, I., and Kuang, S. (2008). The molecular regulation of muscle stem cell function. Cold Spring Harb. Symp. Quant. Biol. 73, 323-331. doi:10.1101/sqb.2008.73.064

Ryan, M. J., Jackson, J. R., Hao, Y., Leonard, S. S., and Alway, S. E. (2011). Inhibition of xanthine oxidase reduces oxidative stress and improves skeletal muscle function in response to electrically stimulated isometric contractions in aged mice. Free Radic. Biol. Med. 51, 38-52. doi:10.1016/j.freeradbiomed.2011.04.002

Ryan, M. J., Jackson, J. R., Hao, Y., Williamson, C. L., Dabkowski, E. R., Hollander, J. M., et al. (2010). Suppression of oxidative stress by resveratrol after isometric contractions in gastrocnemius muscles of aged mice. J. Gerontol. A Biol. Sci. Med. Sci. 65, 815-831. doi:10.1093/gerona/glq080

Sambasivan, R., Yao, R., Kissenpfennig, A., Van Wittenberghe, L., Paldi, A., GayraudMorel, B., et al. (2011). Pax7-expressing satellite cells are indispensable for adult skeletal muscle regeneration. Development 138, 3647-3656. doi:10.1242/dev. 067587

Schmalbruch, H., and Hellhammer, U. (1977). The number of nuclei in adult rat muscles with special reference to satellite cells. Anat. Rec. 189, 169-175. doi:10.1002/ar.1091890204

Schmalbruch, H., and Lewis, D. M. (2000). Dynamics of nuclei of muscle fibers and connective tissue cells in normal and denervated rat muscles. Muscle Nerve 23, 617-626. doi:10.1002/(SICI)1097-4598(200004)23:4<617::AID-MUS22>3. $0 . \mathrm{CO} ; 2-\mathrm{Y}$

Schultz, E., Gibson, M. C., and Champion, T. (1978). Satellite cells are mitotically quiescent in mature mouse muscle: an EM and radioautographic study. J. Exp. Zool. 206, 451-456.

Seale, P., Ishibashi, J., Scime, A., and Rudnicki, M. A. (2004). Pax7 is necessary and sufficient for the myogenic specification of CD45+:Scal+ stem cells from injured muscle. PLoS Biol. 2:E130. doi:10.1371/journal.pbio.0020130

Seale, P., and Rudnicki, M. A. (2000). A new look at the origin, function, and "stemcell” status of muscle satellite cells. Dev. Biol. 218, 115-124. doi:10.1006/dbio. 1999.9565

Seale, P., Sabourin, L. A., Girgis-Gabardo, A., Mansouri, A., Gruss, P., and Rudnicki, M. A. (2000). Pax7 is required for the specification of myogenic satellite cells. Cell 102, 777-786. doi:10.1016/S0092-8674(00)00066-0

Shefer, G., Rauner, G., Yablonka-Reuveni, Z., and Benayahu, D. (2010). Reduced satellite cell numbers and myogenic capacity in aging can be alleviated by endurance exercise. PLoS ONE 5:e13307. doi:10.1371/journal.pone.0013307

Sinha, M., Jang, Y. C., Oh, J., Khong, D., Wu, E. Y., Manohar, R., et al. (2014). Restoring systemic GDF11 levels reverses age-related dysfunction in mouse skeletal muscle. Science 344, 649-652. doi:10.1126/science.1251152

Siu, P. M., and Alway, S. E. (2009). Response and adaptation of skeletal muscle to denervation stress: the role of apoptosis in muscle loss. Front. Biosci. 14:432-452. doi: $10.2741 / 3253$

Sjostrom, M., Lexell, J., and Downham, D. Y. (1992). Differences in fiber number and fiber type proportion within fascicles. A quantitative morphological study of whole vastus lateralis muscle from childhood to old age. Anat. Rec. 234, 183-189. doi:10.1002/ar.1092340205

Snijders, T., Verdijk, L. B., Smeets, J. S., McKay, B. R., Senden, J. M., Hartgens, F., et al. (2014a). The skeletal muscle satellite cell response to a single bout of resistance-type exercise is delayed with aging in men. Age (Dordr.) 36, 9699. doi:10.1007/s11357-014-9699-z

Snijders, T., Wall, B. T., Dirks, M. L., Senden, J. M., Hartgens, F., Dolmans, J., et al. (2014b). Muscle disuse atrophy is not accompanied by changes in skeletal muscle satellite cell content. Clin. Sci. (Lond.) 126, 557-566. doi:10.1042/CS20130295

Snijders, T., Verdijk, L. B., and van Loon, L. J. (2009). The impact of sarcopenia and exercise training on skeletal muscle satellite cells. Ageing Res. Rev. 8, 328-338. doi:10.1016/j.arr.2009.05.003

Snow, M. H. (1977). The effects of aging on satellite cells in skeletal muscles of mice and rats. Cell Tissue Res. 185, 399-408. doi:10.1007/BF00220299

Sousa-Victor, P., Gutarra, S., Garcia-Prat, L., Rodriguez-Ubreva, J., Ortet, L., RuizBonilla, V., et al. (2014). Geriatric muscle stem cells switch reversible quiescence into senescence. Nature 506, 316-321. doi:10.1038/nature13013

Spiegelman, B. M. (2007). Transcriptional control of mitochondrial energy metabolism through the PGC1 coactivators. Novartis Found. Symp. 287, 60-63. doi:10.1002/9780470725207.ch5
Stenholm, S., Harris, T. B., Rantanen, T., Visser, M., Kritchevsky, S. B., and Ferrucci, L. (2008). Sarcopenic obesity: definition, cause and consequences. Curr. Opin. Clin. Nutr. Metab. Care 11, 693-700. doi:10.1097/MCO.0b013e328312c37d

Stepto, N. K., Benziane, B., Wadley, G. D., Chibalin, A. V., Canny, B. J., Eynon, N., et al. (2012). Short-term intensified cycle training alters acute and chronic responses of PGClalpha and cytochrome $\mathrm{C}$ oxidase IV to exercise in human skeletal muscle. PLoS ONE 7:e53080. doi:10.1371/journal.pone.0053080

Suetta, C., Frandsen, U., Mackey, A. L., Jensen, L., Hvid, L. G., Bayer, M. L., et al. (2013). Ageing is associated with diminished muscle re-growth and myogenic precursor cell expansion early after immobility-induced atrophy in human skeletal muscle. J. Physiol. 591, 3789-3804. doi:10.1113/jphysiol.2013.257121

Suetta, C., Hvid, L. G., Justesen, L., Christensen, U., Neergaard, K., Simonsen, L., et al. (2009). Effects of aging on human skeletal muscle after immobilization and retraining. J. Appl. Physiol. (1985) 107, 1172-1180. doi:10.1152/japplphysiol. 00290.2009

Sullivan-Gunn, M. J., and Lewandowski, P. A. (2013). Elevated hydrogen peroxide and decreased catalase and glutathione peroxidase protection are associated with aging sarcopenia. BMC Geriatr. 13:104. doi:10.1186/1471-2318-13-104

Szczesny, B., Olah, G., Walker, D. K., Volpi, E., Rasmussen, B. B., Szabo, C., et al. (2013). Deficiency in repair of the mitochondrial genome sensitizes proliferating myoblasts to oxidative damage. PLoS ONE 8:e75201. doi:10.1371/journal. pone.0075201

Tidball, J. G. (2005). Inflammatory processes in muscle injury and repair. Am. J. Physiol. Regul. Integr. Comp. Physiol. 288, R345-R353. doi:10.1152/ajpregu. 00454.2004

Tidball, J. G., and Wehling-Henricks, M. (2007). Macrophages promote muscle membrane repair and muscle fibre growth and regeneration during modified muscle loading in mice in vivo. J. Physiol. 578, 327-336. doi:10.1113/jphysiol. 2006.118265

Tinetti, M. E. (2001). Where is the vision for fall prevention? J. Am. Geriatr. Soc. 49, 676-677. doi:10.1046/j.1532-5415.2001.49132.x

Toledo, M., Busquets, S., Ametller, E., Lopez-Soriano, F. J., and Argiles, J. M. (2011). Sirtuin 1 in skeletal muscle of cachectic tumour-bearing rats: a role in impaired regeneration? J. Cachexia Sarcopenia Muscle 2, 57-62. doi:10.1007/s13539-0110018-6

Toth, K. G., McKay, B. R., De Lisio, M., Little, J. P., Tarnopolsky, M. A., and Parise, G. (2011). IL-6 induced STAT3 signalling is associated with the proliferation of human muscle satellite cells following acute muscle damage. PLoS ONE 6:e17392. doi:10.1371/journal.pone.0017392

van der Meer, S. F., Jaspers, R. T., Jones, D. A., and Degens, H. (2011a). The time course of myonuclear accretion during hypertrophy in young adult and older rat plantaris muscle. Ann. Anat. 193, 56-63. doi:10.1016/j.aanat.2010.08.004

van der Meer, S. F., Jaspers, R. T., Jones, D. A., and Degens, H. (2011b). Time-course of changes in the myonuclear domain during denervation in young-adult and old rat gastrocnemius muscle. Muscle Nerve 43, 212-222. doi:10.1002/mus.21822

Vasilaki, A., and Jackson, M. J. (2013). Role of reactive oxygen species in the defective regeneration seen in aging muscle. Free Radic. Biol. Med. 65, 317-323. doi:10.1016/j.freeradbiomed.2013.07.008

Velleman, S. G., Zhang, X., Coy, C. S., Song, Y., and McFarland, D. C. (2010). Changes in satellite cell proliferation and differentiation during turkey muscle development. Poult. Sci. 89, 709-715. doi:10.3382/ps.2009-00467

Verdijk, L. B., Dirks, M. L., Snijders, T., Prompers, J. J., Beelen, M., Jonkers, R. A., et al. (2012). Reduced satellite cell numbers with spinal cord injury and aging in humans. Med. Sci. Sports Exerc. 44, 2322-2330. doi:10.1249/MSS. 0b013e3182667c2e

Verdijk, L. B., Gleeson, B. G., Jonkers, R. A., Meijer, K., Savelberg, H. H., Dendale, P., et al. (2009). Skeletal muscle hypertrophy following resistance training is accompanied by a fiber type-specific increase in satellite cell content in elderly men. J. Gerontol. A Biol. Sci. Med. Sci. 64, 332-339. doi:10.1093/gerona/gln050

Verdijk, L. B., Koopman, R., Schaart, G., Meijer, K., Savelberg, H. H., and van Loon, L. J. (2007). Satellite cell content is specifically reduced in type II skeletal muscle fibers in the elderly. Am. J. Physiol. Endocrinol. Metab. 292, E151-E157. doi:10.1152/ajpendo.00278.2006

Verdijk, L. B., Snijders, T., Drost, M., Delhaas, T., Kadi, F., and van Loon, L. J. (2014). Satellite cells in human skeletal muscle; from birth to old age. Age (Dordr.) 36, 545-547. doi:10.1007/s11357-013-9583-2

Vescovo, G., Volterrani, M., Zennaro, R., Sandri, M., Ceconi, C., Lorusso, R., et al. (2000). Apoptosis in the skeletal muscle of patients with heart failure: 
investigation of clinical and biochemical changes. Heart 84, 431-437. doi:10. 1136/heart.84.4.431

Vescovo, G., Zennaro, R., Sandri, M., Carraro, U., Leprotti, C., Ceconi, C., et al. (1998). Apoptosis of skeletal muscle myofibers and interstitial cells in experimental heart failure. J. Mol. Cell. Cardiol. 30, 2449-2459. doi:10.1006/jmcc.1998.0807

Vettor, R., Milan, G., Franzin, C., Sanna, M., De Coppi, P., Rizzuto, R., et al. (2009). The origin of intermuscular adipose tissue and its pathophysiological implications. Am. J. Physiol. Endocrinol. Metab. 297, E987-E998. doi:10.1152/ajpendo. 00229.2009

Vinciguerra, M., Fulco, M., Ladurner, A., Sartorelli, V., and Rosenthal, N. (2010). SirT1 in muscle physiology and disease: lessons from mouse models. Dis. Model Mech. 3, 298-303. doi:10.1242/dmm.004655

von, M. J., Jones, A. E., Parks, R. J., and Rudnicki, M. A. (2013). Pax7 is critical for the normal function of satellite cells in adult skeletal muscle. Proc. Natl. Acad. Sci. U.S.A. 110, 16474-16479. doi:10.1073/pnas.1307680110

Wang, H., Lai, Y. J., Chan, Y. L., Li, T. L., and Wu, C. J. (2011). Epigallocatechin-3gallate effectively attenuates skeletal muscle atrophy caused by cancer cachexia. Cancer Lett. 305, 40-49. doi:10.1016/j.canlet.2011.02.023

Wang, X., Pickrell, A. M., Rossi, S. G., Pinto, M., Dillon, L. M., Hida, A., et al. (2013). Transient systemic mtDNA damage leads to muscle wasting by reducing the satellite cell pool. Hum. Mol. Genet. 22, 3976-3986. doi:10.1093/ hmg/ddt251

Welch, A. A. (2014). Nutritional influences on age-related skeletal muscle loss. Proc. Nutr. Soc. 73, 16-33. doi:10.1017/S0029665113003698

Welch, A. A., MacGregor, A. J., Minihane, A. M., Skinner, J., Valdes, A. A., Spector, T. D., et al. (2014). Dietary fat and fatty acid profile are associated with indices of skeletal muscle mass in women aged 18-79 years. J. Nutr. 144, 327-334. doi:10.3945/jn.113.185256

Westerbacka, J., Kolak, M., Kiviluoto, T., Arkkila, P., Siren, J., Hamsten, A., et al. (2007). Genes involved in fatty acid partitioning and binding, lipolysis, monocyte/macrophage recruitment, and inflammation are overexpressed in the human fatty liver of insulin-resistant subjects. Diabetes 56, 2759-2765. doi: $10.2337 / \mathrm{db} 07-0156$

Wilson, G. J., Wilson, J. M., and Manninen, A. H. (2008). Effects of beta-hydroxybeta-methylbutyrate (HMB) on exercise performance and body composition across varying levels of age, sex, and training experience: a review. Nutr. Metab. (Lond.) 5, 1-17. doi:10.1186/1743-7075-5-1

Wu, D., Wang, J., Pae, M., and Meydani, S. N. (2012). Green tea EGCG, T cells, and T cell-mediated autoimmune diseases. Mol. Aspects Med. 33, 107-118. doi:10.1016/j.mam.2011.10.001

Xu, Z., Huang, G., Gong, W., Zhou, P., Zhao, Y., Zhang, Y., et al. (2012). FXR ligands protect against hepatocellular inflammation via SOCS3 induction. Cell. Signal. 24, 1658-1664. doi:10.1016/j.cellsig.2012.04.015

Yablonka-Reuveni, Z., Day, K., Vine, A., and Shefer, G. (2008). Defining the transcriptional signature of skeletal muscle stem cells. J. Anim. Sci. 86, E207-E216. doi:10.2527/jas.2007-0473

Conflict of Interest Statement: The authors declare that the research was conducted in the absence of any commercial or financial relationships that could be construed as a potential conflict of interest.

Received: 18 June 2014; accepted: 01 September 2014; published online: 22 September 2014.

Citation: Alway SE, Myers MJ and Mohamed JS (2014) Regulation of satellite cell function in sarcopenia. Front. Aging Neurosci. 6:246. doi: 10.3389/fnagi.2014.00246 This article was submitted to the journal Frontiers in Aging Neuroscience.

Copyright (C) 2014 Alway, Myers and Mohamed. This is an open-access article distributed under the terms of the Creative Commons Attribution License (CC BY). The use, distribution or reproduction in other forums is permitted, provided the original author(s) or licensor are credited and that the original publication in this journal is cited, in accordance with accepted academic practice. No use, distribution or reproduction is permitted which does not comply with these terms. 